\title{
泌尿生殖器結核の化學療法
}

\author{
東京大學醫祭部泌家器科呚室 \\ （主任：书川篤二呚授） \\ 諽師堀內 誠 三

\section{CHEMOTHERAPY OF GENITOURINARY TUBERCUROSIS}

\author{
Seizō Horiuchi \\ From the Urology Department, Medical Faculty, University of Tokyo
}

(Director: Prof. Dr. T. Ichikawa)

（本䄖文の要旨は昭和 $26 ， 28 ， 29$ 年第39，41，42回日本泌尿器科學會總會に於いて發表した）

\section{I. 緒 言}

Waksman の Streptomycin ( $\mathrm{SM}$ ) の發見以來 Paraaminosalicylic Acid (PAS), 4-Acetylaminobenzaldehyde thiosemicarbozone ( $\mathrm{T} \mathrm{B} \mathrm{I}$ ), Isonicotinic Acid hydrazide ( I NAH), Sodium isonicotynyl hydrazide methansulfonate (I HMS ) 等 と相次いで抗結核劑が出現し，人體の結核症て㷳用され て，結核治療上に一大進步交來した。

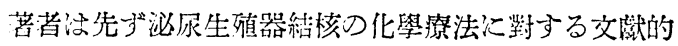
洘察党行い, 主としてSM, T B I, INAH, I HM

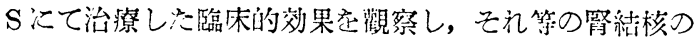

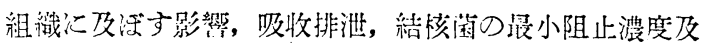
び而性等こついて憸索した絬果を報告する。

\section{II. 文塥的考察}

A. Streptomycin

Waksman 等化尗 Streptomyces grieseus から分

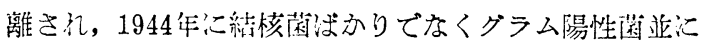

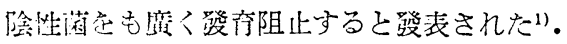

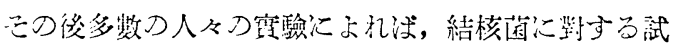

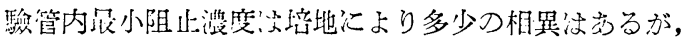

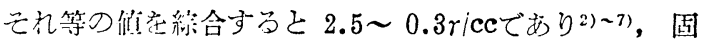

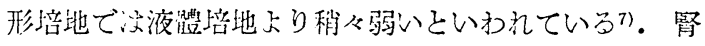

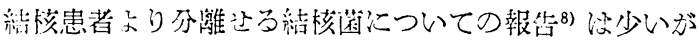

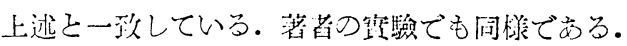

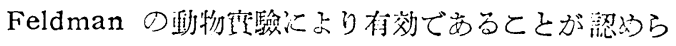

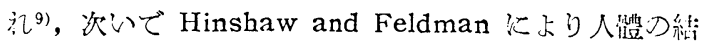

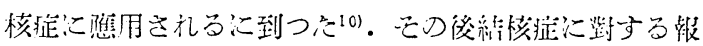

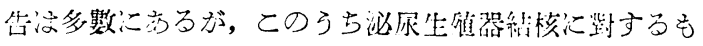
のについて考察して々上う111ー84)。

1）霄結核
腎結核化對するS M治療の晨初の報告は Hinshaw 等 の63例の報告中に11例の腎結核患者が含まれて坛り ${ }^{10)}$ ， 有効なととについての報告は内外非常に多歡に犁つてい る.

こ记等の發表から現在一致した見解をのベてるよう。

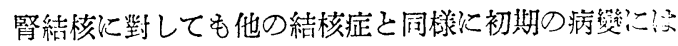
効果が期待される。例えばSMのみで治療した Latti-

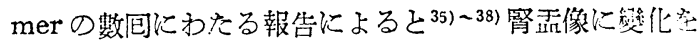
涊められない程度の腎結核は化學療法のみで治湶す气可 能性が多く, SM療法により 2 年後の尿中結核菌除性化 ほ $90 \%$ でり，4 年後汇は約80\%の陰性化を示している

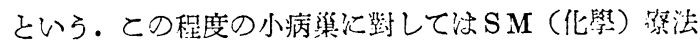
の文で治癌するとの意見には替成者が多い。

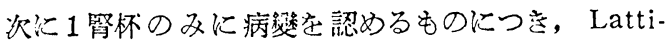

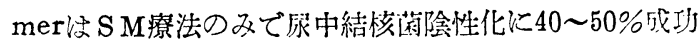

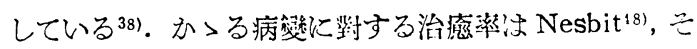

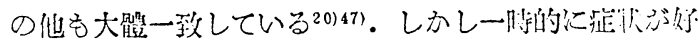

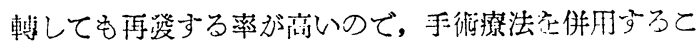

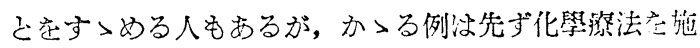

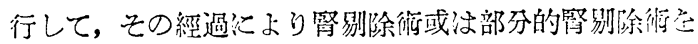
行うことを主張する人も多(20833335)40)50)51)541.

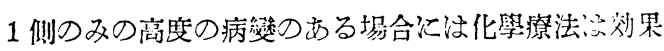

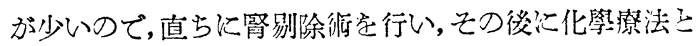

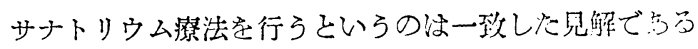
が，婜絬榜が他の結㤥症の 2 次的感染でるといら落え

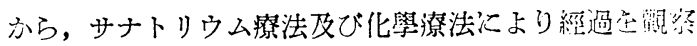

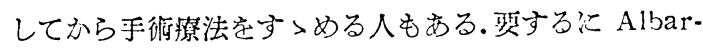
ran, Wildbolz 以來の踐埧 néphreotomie immediate より, Feyの néphrectomie retardée ${ }^{67}$ 或以 Moonen のいう néphrectomie opportune の方針をとるべきで 
あるという意見が有力に成つて來た ${ }^{32) 40) 68) . ~}$

兩側腎結核については, 上記の法則と同様であり, 兩 側の病變が輕度の場合には先ず化學療法のみで治療して 經過を觀察し, 病笨の變化により, 治療の効果の認めら 礼ない側を, 或は剔除し, 或は部分的腎剔除術を施行す る. 又1側が輕度で他側が高度であるか, 又は閉塞性で ある場合には化學療法索充分行つて剔除し, その後も長 期の化學療法安續ける. 兩側高度の病變のある例は化學 療法により生命の延長を計るべきである。

Medlar ${ }^{69)}$ によれば腎結核は殆んご网側性であるとい われているので，たこえ1侧の及が症狀を現わしていて も, 他側が犯されている場合も充分考えねばならないの で, 手術後の化學療法は少くとも6 ケ月以上は必要であ り，それにより残㛑結核の發生学防止するととが大切で ある.

又1側腎結核患者の腎剔除後の永久治瘾率は, 化學療 法施行前40年間の發表によれば64いづれも50\%内外であ り，その死亡の原因は結核性病變が大部分である。この 事は腎結核が 2 次的結核であり, 且つ腎剔除術のみによ り解決し得ないととを示し, 化學療法がこの意味でも重 要な役割を演ずるととは當然考えられる.當敎室の報告 もこれ走している70).

以上のととは單にS Mのみならず，化學療法一般に對 する見解である。

SM使用量及び期間については，SMの發表された當 初より現在迄にはかなりの變遷をみている. 初期には1 $\mathrm{g}$ 毎12時間法, $0.5 \mathrm{~g}$ 每12時間法, $0.3 \sim 0.6 \mathrm{~g}$ 毎 6 時間 法等があり, その期間も最短40日より90日或は 120 日治 療孛 1 クールとしたが, SM單獨療法では副作用が強 く, 約40〜 $60 \mathrm{~g}$ で抵抗性が出現する事實を知つたので ${ }^{0)}$ 48)66), 單獨療法は否定されるに到り, Paraaminosalicylic Acid (PAS) との併用が用いられている.

S M 使用後の尿管狭窄については Rinker の報告 ${ }^{53)}$ 以 來しばしば報告されて拉り71) 73), 腎血の狭窄も報告さ れている ${ }^{74) 75)}$. 從つて結核菌尿の消失及び尿所見の改善 も上述の尿管, 腎貫の狭窄による閉塞に起因するととも あり，その䉆に病集の惡化が起り得るとともあるので注 意要要する.

種々の細菌がS M 對する抵抗性を容易に獲得するこ とは知られているが, 結核菌も同樣にS M耐性菌に成る. Youmans 等の試驗管内實驗による抵抗性の増加の發表 以來，人體の結核症に打ける SM耐性菌出現の報告は多 い. 腎結核に於いてもS M治療による結核菌のS M 而性
出現が報告されている，Emmett等によればSM 1 日 I $\mathrm{g}$ 使用 6 週で約 $1 / 3$ は耐性菌と成り, 120 日では結核菌 尿学示す全症例とむ耐性であるといわれ20), Lattimer 等の1日 $1 \mathrm{~g}, 120$ 日治潦後の再發例は全症例とも耐性 菌であると云う ${ }^{37)}$. 耐性菌とば何 $\gamma / \mathrm{cc}$ 以上を阻止しない. 場合字言うのかは人により多少相異があるが，大體10 r で酎性菌としている人が多い501・しふしその耐性菌も對 照に生青した結核菌に對する\%が問題に成る場合も多い. ので, 固形培地に發育させ對照と比較して何 $\gamma$ 耐性菌が. 何\%出現したとする方法がよいともいわれている.

尚耐性菌が出現しても治療字繼續すると, 臨休的に效 果字示す場合も報告されている37)45). この點について は，耐性菌が全結核菌の何\%をしめているかということ が, 臨床効果定左右するのであろう. S M使用例で腎と 他藏器から分離した結核菌の耐性が同様に出現するとは かぎらいと言われている。

SM療法後の腎組織像に及ぼす影響については，警結 核の組織像が非常に多様であるので種々言われている. 今とれ等のうち比較的多くの人々が認め得たとこを中心 として觀察してタる。

S M治療により，腎結核の病巢には䢧出性機轉の抑制 そ吸收の促進が起り，周局炎が消退する76) -79)・結核結:

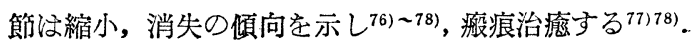
類上皮細胞及び巨細胞は萎縮變形を示す76) -79) ・腎孟と 交通ある空洞壁は清浄化を示し，上皮再生を認める76) 79) 81) 84). 又結核性肉芽内に毛細血管の新生を認める73)76) 84).

結合織については增殖が著明であつたと云う報告も認 められるが12) 80) 82), 又膠原線維の增殖を認める人もあ る ${ }^{81)}$. 佐々は Fibrillosis を示すという76).

結核結節はS Mにより硬化型を示すという説 ${ }^{821}$ に對し て，か〉る硬化型には影響がない(78) ${ }^{83)}$ か或は少いともい われている84)。

その他組織エオジノフイリーを認めている人もあり ${ }^{2}{ }^{6}$, 綜合的に治癒傾向は想められるけれども完全な閉塞 ではないという人もあり ${ }^{399}$ ，全く特記すべき變化はない という人もある16)58)

Dick は耐性菌が出現すると空洞壁に急性の乾酪性變 化学認めるという ${ }^{83)}$. 尚彼は S M と P A S の併用治療例

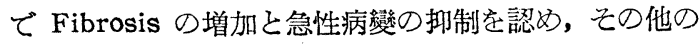
變化は S M 單獨治療と全く同様であり, PA S, Terramycin, Neomycin 等は單にS M 耐性菌出現の防止のみ の作用であろうという ${ }^{84)}$ 。 


\section{2) 膀胱結核}

S M治療が膀胱粘膜に著明な効果を示す報告は多數認 められる. 即ち自覺症狀の消失, 膀胱鏡所見の改善, 菌 の消失てあり，殊に浅い潰瘍は結核菌尿の存在するにす 拘らず治癒することもまれでない.しかしかっる例では S M中止により再發を見ることもまれでい. 膀胱壁の 深尿儿迄揖よぶ結核性の變化と，長期にわたる拘縮を示 す例では改善を望及得ない場合がある許りか, 萎縮膀胱 に成ることも多い。

3）前立腺結核

前立腺結核の際に前立腺内に觸診し得る結節は， SM 治療とは無關係に大きく成るし，治療中に新しい結節が 現われるとともあり，一般に本疾患は乾酪性變化を示す ものであるから化學療法の效果は期待し難い. 多くの發 表も效果不充分としている。たざ膿瘍が尿道に破れた場 合は著効を呈するという ${ }^{81)}$.

4) 副宰丸結核

副滓丸内の慢性の結核性浸潤には化學療法で効果は期 待されず, 急性の場合には S M 療法で漸時改善されるも のもあるが, てれは化學療法をしなくても同等の改善が あるもので判定は困難である.だ゙ S M療法を施行する と皮膚に破壊し難く成るし, 難治の瘦孔も治癒せしめ得 るという・

以上の事實より，副䅅丸結核は化學療法施行のもとに 剔除するがよいといわれている。

吸收及び排泄：

米國ではカツプ法によるSMの定量法が發表された が, その後の報告によれば低濃度の測定には稀釋法並に 比濁法が用いられて招り本邦では鳥居等の重層法 ${ }^{86)}$ とカ ツプ法の改善による變法 ${ }^{87)}$ が用いられている。

\section{イ）血中濃度}

カツプ法も重層法も殆んご同㥞な值を報告して居り, 著者の重層法による測定も一致している ${ }^{88)}$ ＳＳM $0.5 \mathrm{~g}$ 毎12時間法で注射後30分より 1 時間は10〜 40 r/cc 2 時間 後は急激に減少し, 12 時間後に痕跡より 4 r c c 位にな る.

\section{口）尿中濃度}

SM尿中排泄については毎12時間 $0.5 \mathrm{~g}$ 筋注の場合, 尿量に左右されてかなりの差はあるけれども, 最高 1600 〜 1400r/cc 排泄され, 總排泄量は 40～90\%前後こ云わ

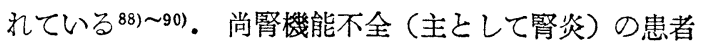
では同様な注射で 700r/cc以上は排泄されず，24時間て 4.3〜26.1\%が排泄されるにすぎなと云われている93).
八) 臓器内濃度

多くの發表を綜合すると䭪91)92)，尿〉血清〉腎〉副䛭 丸>肺〉箤丸の順であるが，腎と血清が反對の報告もあ る.

）腎病巢内濃度

著者は石山と共に剔除腎病變部の S M 濃度を測定した 88)，腎の健康部は一番高く，空洞壁は低濃度であり，空 洞内经更に低かつた. その後同様の報告がある ${ }^{89) 90)}$.

副作用:

筋肉内注射による局所の疼痛，發赤及び硬結などがあ るが, 最も重大なものは第 8 腦种經障害でめまい, 耳 鳴, 頭痛等がある. 㛑刺㦸症狀こして圓柱尿, 蛋白尿及 び血尿があるが, 泌尿器結核の場合は判定が困難な場合 もある. 過敏反應として, 發熱, 發疹, 皮膚炎, エオジ ン好性細胞増加等があげられている。

Dihydrostreptomycin (D S M) :

D S M 2 S Mの還元型で, 試驗管内賽驗では, 阻止力 はSMと殆んど同様か，稍々弱いといわれている4.

動物實驗は Feldman等94)より行われ，SM感受性 菌感染には効果があるが，SM耐性菌感染には S M と同 様效果が少い.

吸收，排泄に關しても S M 殆んど同様であるといわ れている95)。

米國では SMは副作用が少いが，效果も劣るのて結 核症には主としてSMが用いられている。 Nesbit 等の 如くD S Mを用いている人もある。

副作用として三半器官の障害によるものが最も重大な ものである。

本邦ではD S Mが配給された關係上, 著者のS M治療 は主としてD SMによるものである。

\section{B. Paraaminosalicylic Acid}

$\mathrm{COOH} \quad \mathrm{PAS}$ ( 2 hydro-4-aminosalicylic AcOH id) は1902年 Seidal and Bittner に よつて合成されたもので95)，1944年 Lehmann によつて抗結核劑として着目され

$\mathrm{NH}_{2}$ $た^{97)}$.

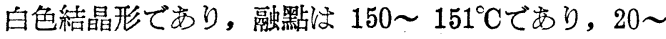
$25^{\circ} \mathrm{C} て ゙ は ~ 0.1 \%$ 溶解するに過ぎなが, 本劑を炭酸ナト リウム又は重曹を以て中和すると PASの Na 監と成 る. $\mathrm{Na}$ 監は水溶性であり, 副作用も少い. 又近時 $\mathrm{Ca}$ 監も用いられている。

Lehmann は Sauton 培地により $0.15 \mathrm{mg} / \mathrm{dl}$ で抗結核 
菌作用のあることを知つた。 その後の最小阻止濃度の發 表を綜合すると(5)689) 0.078〜0.19mg\%である．著者の 腎結核患者より分離せる菌についても上述の値に一致し ている.

Lehmann 等による動物の賽驗結核では有効であると の報告あり，1944年彼により肺結核患者に使用された。

泌尿性殖器結核については多數例に試及た報告は少 (199) 102).

\section{1）腎結核}

PA S が䐌結核に効果を示すと云う報告は，SMと同 椂に病變初期のもので長期の使用によるものと考えられ るが(00) 102)，一方短時閒の報告では治瘾の攧向学認めな い例が多い991 100)。結局 P A S の單獨療法では効果が不 充分である故珡結核治療には現在一般に用いられていな い. この點化つき Dick 牥PAＳの作用を S M 耐性の防 止以外飞注ないという ${ }^{84}$.

2）膀胱結核

膀胱結核については症狀の輕快, 潰瘍の消失を認め る ${ }^{99) \sim 102)}$.

3）副宰丸結核及び前立腺結核

効果注不充分なりとする人が多い。

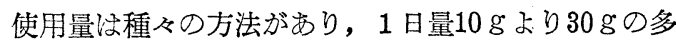
量安投與する人もあるが，現在米國では $12 \mathrm{~g}$ が普通用い られ，SMと併用されている。尚PA S は腎より多量に 排泄される故 $4 \mathrm{~g}$ でよいとする人もある65)。期間も人に より一定せず休藥期間をおく人もあつたが，現在は S M 併用の連續治療が多いょうである. 又投藥の時間も毎 3 , 毎 4 , 毎 6 , 毎12時間法等がある.

Lehmann ほ抵抗性の出現を見ないと發表した. 實際 試驗管内で耐性菌の出現を認內難かつたという報告もあ るが，PAS使用の肺結核患者より耐性菌を分離した報 告もあり ${ }^{104)}$ ，腎結核患者亦らも PAS 捄性菌を分離し たという報告がある. S M に比して耐性菌の出現が遲い ことは事賽である。而性菌による動物賽驗では效果は殆 んでないといわれている。

吸收及排泄:

PASの定量法にはBratton-Marshall變法 ${ }^{105)}$, Way 法 $^{106)}$, Alin 等の方法 ${ }^{107)}$ 等が行われている.

1) 血中濃度

發表者汇より多少の差はあるが $2 \mathrm{~g}$ 經口投與で最高 7 $\sim 9 \mathrm{mg} / \mathrm{dl}, \quad 3 \mathrm{~g} て ゙ 11 \mathrm{mg} / \mathrm{dl}$ に達し， $5 \mathrm{~g}$ 服用後は 8 㭙間， $2 \sim 4 \mathrm{~g}$ では約 6 時間, 結核菌發育抑制的であるという 108). 一方 Brodie 2 PAS-Na監 $3 \mathrm{~g}$, 毎 3 時間經口 投與により，血中に $6 \mathrm{mg} / \mathrm{dl}$ 維持するけれども， $2 \mathrm{~g}$ では
3 時間後に $2 \mathrm{mg} / \mathrm{dl}$ 迄下る故不充分であるという. 口) 尿中濃度

經口投與により尿中に排泄された P A S の濃度は測定 者により相異があり，10時間以内で85\%が排泄されると 云う人もあり ${ }^{106) ， 24}$ 㭙間で 40 ～ $60 \%$ がアセチル化して 排泄されるとも云われている108)，その濃度も $45 \sim 50 \mathrm{mg}$ /dlである。

\section{八) 臟器内濃度}

腎＞血液＞肺＞肝の順であるという ${ }^{106)}$.

）筲病巢内濃度

坂本によ机ば，PA S も剔除腎の健康部に洨比較的多 量に存在するが，病變部に淰排泄が不良であるという ${ }^{80)}$.

尚PASの排泄安遲延せしめる第に Caronamide ${ }^{108)}$ 或は Benemid ${ }^{109}$ )用い，その血中濃度を $2 \sim 4$ 倍化 したとの報告がある。

副作用:

胃腸障害として惡心, 嘔吐, 下㾥等が認められるが, $\mathrm{Na}$ 監, 更に顆粒 P A S , Ca 監等の出現で比較的少く 成つた。腎障害として蛋白尿, 血尿, 結晶尿等がある. 時に發熱と皮痛刺戟も認められる. 皮疹としては癌痒性 の紅斑, 中毒性發疹があり, 發熱と發疹注全症例 $2 \sim 4$ \%に認められるという。

\section{4-Acetylaminobenzaldehyde thiosemicarbazone (TBI)}

Domagk Sulfathiazole に抗結核菌作用のあるこ と着目し， thiosmeicarbazone の結核菌阻止力のあ るととより，I B I が最も有効であることを知り，1948 年に發表した ${ }^{111)}$.

$\mathrm{TBI} \mathrm{CH}_{3} \mathrm{CONH} \longrightarrow \mathrm{CH}: \mathrm{N} \cdot \mathrm{NH} \cdot \mathrm{CS} \cdot \mathrm{NH}_{2}$ の示性式安有し, 分解點㹥 $230 \sim 238^{\circ} \mathrm{C}$, 分子量は 236.28 で淡黄色結晶性粉末であり，水，アルコール等に難容で ある112)

Domagk によればその試驗管内に於ける結核菌の最 小阻止濃度は $5 \sim 3.3 r^{\prime}$ (ccであるという ${ }^{113)}$. 本邦代於け る發表で汶製品汇より阻止力が非常に弱いものもあるけ れぞも大體 $5 \sim 20 \mathrm{r} / \mathrm{cc}$ 前後である ${ }^{114)}$.

動物の筫驗結核に對して Domagk 注非常に有効であ ると發表したが，米國學派では反對している人もある。

その後ドイツにて1万名の結核症に對する治瞼が報告 され注目に值すると結論された。 
1) 腎結核

Boshamer によればT BIは腎結核に効果を示し, 腎 病䉓は結合織で置きかえられ，空洞は清浄化する．空洞 は結合織でかとまれるが消失せずに殘り，大空洞があつ ても治療 4 力月で結核菌尿の消失した例もある．尿所見 も全體としては改善する。しかし他臟器に活動性病變が ある場合には結核菌尿は消失しない, 本劑は手術不能な る症例に最も有意義である115)。

しかるに本邦製のT B I による自驗例ではドイツ學派 の云う程の組織學的効果はみられず, 治瘾の可能性も少 いと思われる. との點について本邦では効果の少いと云 う報告も認められる116)117)。

組織像の變化䎲ついての報告字まとめると佐々はその 作用は一般に弱く, 長期使用例では時に空洞の清浄化, 上皮再生のある事を認め，類上皮細胞の萎縮，巨細胞の 萎縮を認めるこいう ${ }^{118)}$. 一方空洞壁の結合織の増加, 結 核結節の膠原化, 器質化を認め, 血管の新生をむ認めた という報告もある(19)。

2) 膀胱結核

膀胱の漬瘍，結核結節は極めて高度のものを除いて 1 〜 2 ケ月内に治瘾し, 撉より結核菌尿が排泄されていて も本劑の經口投與で治癒するという115)．此の點に關し ては著者の例も本邦の報告も一致する。

3）前立腺結核及び精囊腺結核

前立腺の空洞には効果が確實ではないが，尿道に排膿 した例には効果があるという ${ }^{115)}$ 、又精囊腺結核に効果 があるという人もある。

4）副金丸結核

乾酪化が起つていないうちならば治瘺するといわれ， Boshamer によれに゙膿瘍形成のある場合も膿瘍が包囊 されて, 病巢の進行は停止し, 從來50\%に見られた他側 えの侵襲も防止し得るという(15).

使用量は初め6 週間は25mg守投與して, 副作用に注意 しながら最大量 $100 \mathrm{mg}$ に増量すべきであるこいう。

吸收及び排泄:

種々の方法により測定した文獻がある，即ち銅錯譼に よる方法, Wollenberg 法, W-Chlor acetophenone に よる方法, Wollenberg 變法 ${ }^{120)}$, Heilmeyer 法 ${ }^{121)}$, イ ンドール加による尿中定量法があるが，方法により，測 定值が一定しない。

1）血中濃度

經口投與により 4 時間で最高に達し， 8 時間で急激に 下降し，24時間で消失亗とい:う。
$50 \mathrm{mg} 2$ 包投與では $0.2 \mathrm{mg} \%$ ，50mg 4 包投與では 0.4 $0.5 \mathrm{mg} \%$ 血中濃度を持續する故，1日 $100 \mathrm{mg}$ 以下では 効果字期待し得ないという.

口）尿中濃度

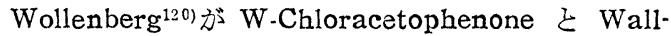
enberg の變法によつて測定した值も相當の差が認めら れている. 測定法による相異については Simos 等の報 告もある.

結論としてT B I の吸收, 排泄は微量であるために良 い方法がなく，個人差も強いものであろう.

ドイツ學派によれば抵抗性は出現しないと發表した が, その後試驗管内實驗でも, 人體より分離せる菌も抵抗

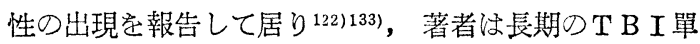
獨治療の腎結核患者より耐性 100r/ccのものを認めた。

副作用:

胃腸障害こしては食愁不振, 惡心, 嘔吐等であり, 腦 障害としては頭痛及び腦壓六進の症狀が多い。その他蛋 白尿, 結膜炎, 發疹を示しへモグロビン及び赤血球の減 少, 血清ビルルビンの増加, 尿中ウロビリノーゲン, ウ ロビリンの排泄増加を認める. 又注意すべきととは白血 球の減少とアグラヌロチトーゼである. 時に出血時間, 凝固時間の延長己肝障害学認める.

本劑以効果が不充分で, 副作用が強いので, アメリカ ではは殆んぞ使用されず, ドイッ學派で一部使用してい るにすぎない。

\section{4 (P-Ethylsulfonal benzaldehyde} thiosomicarbazone)（P54[森永製藥]と略す）

1949年英國の Hoggarth 等により本劑がマウスの賽簽 結核に於てT B I より強力であると發表された ${ }^{244}$.

本劑は $\mathrm{C}_{2} \mathrm{H}_{5} \cdot \mathrm{SO}_{2} \backslash \mathrm{CH}: \mathrm{N} \cdot \mathrm{NH} \cdot \mathrm{CS} \cdot \mathrm{NH}_{2}$ な る示性式で，带黄白色粉末である．血中濃度も高く且つ 長く倠持されるという。

試驗管内賽驗による最少阻止濃度梳 $2.0 \mu \mathrm{g} / \mathrm{ml}$ であ る125)126!. 本邦に於讨る試驗管内實驗でもT B Iより阻 止执が劣つている.

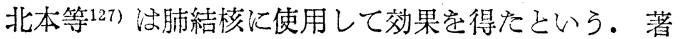
者の少數例の泌尿器結核に應用した効果は，T B I と同 様で S M等に比較して劣つている.

副作用として胃晹障棒, 頭痛, 白血球減少等が報告さ れている128).
E. Isonicotic acid hydrazide (INAH) 
本劑註 T B Iの出現後, その副作用が強いために thiosemicarbazone 誘導體の研究が行われた結果, 米國の

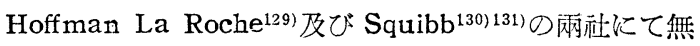
關係に isonicotinic acid 誘導體中に hydrazide が最 も有効であることを知り 1952年の初めに發表された。

ヌドイツでは Domagkが Conteben の改良研究中に 稍とおくれて同じ藥品の有効なるととを知り Neoteben と名命して1952年 5 月に治驗例学表した ${ }^{132}$.

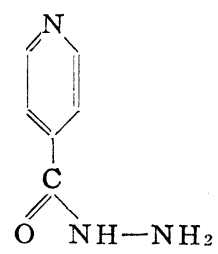

本劑は左の如き化學構造を有す る白色針狀結晶で水に容易にこり て安定である.

結核菌最小阻止濃度は $\mathrm{H} 37 \mathrm{Rv}$ 株に於て $0.02 〜 0.06 \mathrm{r} / \mathrm{cc}$ である己 分離した菌については岩㟝の報告がある ${ }^{135)}$.

米國及びドイツで動物の實驗結核に有効であることが 判り，人體に應用されるに到つた。

人體の結核症に有効であるといろ發表は多數ある が, 泌尿生殖器結核に關する報告は次の通りである 135) (138).

\section{1）腎結核}

尿所見の改善, 結核菌尿の消失, 腎空洞の縮少等の有 効な報告多く, 尿培養でも結核菌陰性と成り, SM耐 性菌にも有効である.しかし $2 \sim 8$ 週間の治療で耐性菌 が出現する. 又治療前にも耐性の存在する例もあるとい $3^{138)}$ ・兩側腎結核で健康なる腎錐體が僅か 2 個しかな い血中残餘窒素の上昇した症例に本劑空使用して血中残 餘窒素が正常に復したという ${ }^{138)}$.

而性菌の出現は上述したが，耐性菌が出現すると效果 も不充分に成る. 本劑の耐性学何 $r / c c$ とするかについ ては10r/ccと主張するものもあり，1 r/ccと云うものも ある. 要するに効果が不充分に成つた場合が問題に成る のであろう・

組織像1181139) に對する影響としては漻出性周局炎の消 退, 類上皮細胞の變形萎縮, 潰場面の清浄化, 上皮再生 が認められている。これを Dick は急性乾酪病巢の吸 收, 類上皮細胞の萎縮, 上皮細胞の成熟とし, その他病 巢周邊部の血管新生, 結合織の消失をも報告している. 尚彼注而性菌が出現すると, 空洞壁に結核性病變が再燃 するという

又 Dick は S M と I NAHの併用例について, SM よ り I NAHの影響が強く表われて, I NAH單獨と殆ん ぞ同様の組織像を示し, 乾酪巢の吸收が著朋で, 病巢内 に出血が多いという。

\section{2）膀胱結核}

本劑が膀胱結核に著効を呈することばすすでに幾多の 報告があり，SMV比肩し得る藥劑である。

3）副睪丸結核・前立腺結核・精裂腺結核

これ等には効果が不充分なりと思われる報告に接するの みである。

四收及び排泄：

定量法についてい當教室より發表がある137).

1）血中濃度

$3 \mathrm{mg} / \mathrm{kg}$ 投與により血中濃度は $1 \sim 3.5 r / \mathrm{cc}$ に昇り, $1 \sim 6$ 時間で最高と成り, 約 12 時間は有効濃度を保つと いう。

口）尿中濃度

$3 \mathrm{mg} / \mathrm{kg}$ 投與後 24 時間で大略 50〜 70\%尿中に排泄され る. その濃度は14時間迄は $47 \sim 191 r / \operatorname{cc}$ の高値と示すを いう.

\section{八) 臟器内濃度}

腎組織こ血液は殆んご同值であり，肝及び肺臟ははる かにひくいという。

$\Rightarrow$ 腎病巢内濃度

I NAHも他の藥劑と同様に剔除腎の健康部には比較 的高濃度に存在するが, 腎病巢部には低濃度である。

副作用:

めまい, 頭痛, 耳鳴, 反射方進, 下肢痓攣, 睡氣, 不 眠, 視覺障害, 排尿開始遲延, 蛋白尿, 精神障害が報告 されている．珡機能の惡い患者は特に病卛に注意すべき であるといわれている138)。

使用量については I NAH は普通 3〜 $5 \mathrm{mg} / \mathrm{kg}$ 割合

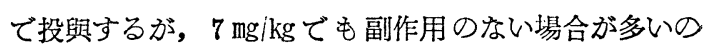
で 300〜 400mgの投與も可能である.

\section{F. Sodium isonicotinyl hydrazide methansulfonate ( I HMS)}

I NAHの出現後, その誘導體の研究は非常に盛んに 成り, 種々の誘導體が發表され, 本邦に於いても I HM $\mathrm{S}$ が登場した. 本劑は左の如き構造式を有する白色の結 晶性粉末であり, 水によく溶ける。

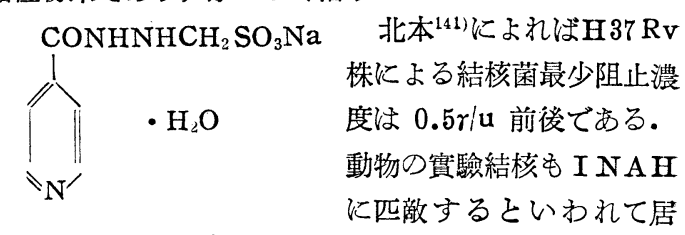

り, 次いで人體の結㭶症に應用された。 


\section{1）腎結核}

既仙當敉室より報告されている通り ${ }^{142}$ ，腎結核患者に 使用して, 永所見, インチゴカルミン排泄時間, 腎孟像 にも好影響をあたえている。

2) 膀胱結核

膀胱症狀の改善, 粘膜の結核性變化に及法卞影響は I NAHと匹敵するという。

使用量は15〜30m/ $/ \mathrm{kg}$ ありり, 從つて成人では $500 \mathrm{mg}$ 〜1000mgにあたる。

尚 I HM S 中㳊含ま记るINAHは次の式から求めら れる。

I NAH量 $=$ I HMS 量 $\times \frac{\text { INAH分子量 }(137)}{\text { I HMS 分子量 }(271)} \fallingdotseq$ I HM S 量

吸收及び排泄

本劑の吸收及び排泄 I NA H と同様の方法を用いて测 定可能であるといわれる。

\section{G. 併用療法}

現在主として用いられる抗結核劑について述べてきた が, このらち著効を呈するの虫, SMとINAH（IH MSを含む)である.しかし，とれ等はいづれも耐性菌 の出現しやすい㑯向があり, 而性の出現と共に効果は不 充分に成るか，場合により無効になる缺點がある，從つ て現在はこれ等の藥劑を併用して, 耐性の出現を阻止し て最も有効汇治療する必要があるといわれている。てれ には當然種々の組合せがあり，且つ好みがある．例えば 米英學派は S M 安中心とし, ドイツ學派は T B Iをも使 用する。これらの方法と期間学列擧して見よう。

Nesbit 等 ${ }^{46)}$ はD S M 1 日 2 g と PAS 1 日 $12 \sim 15 \mathrm{~g}$ を使用し90日間を 1 クールとする. Lattimer 等 ${ }^{37)}$ は最 初S M 1.0毎日とPA S $12 \mathrm{~g}$ 毎日90日間安使用したが， その後 S MO毎 3 日に $1 \mathrm{~g}$ とPAS $12 \mathrm{~g}$ 毎日の間歇裺法 を主張して場合により SMを増量するという ${ }^{38)}$ 。との方 法沈賛成者犬゙多い。

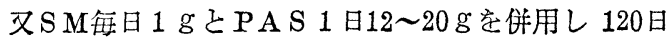
間使用する人もある。

Alken 等 ${ }^{11}$ 《 S M 1 日 1 g kPA S $10 \mathrm{~g}$ 以上を併用 し, SMU230g学 2 名月間隔で 3 包行う.

Cappelln ${ }^{16)}$ は S M 1 日 $1 \mathrm{~g}$ とPA S 12 16 g k Moogrol 每日 $1 \mathrm{cc}$ 併用定施行している。

Ljunggren ${ }^{41}$ 㹥 P A S 毎日 $10 \mathrm{~g}$ を用い，それにD S M 2 日に $1 \mathrm{~g}$ と T B I $0.1 \mathrm{~g}$ 安併用し, Otto ${ }^{511}$ は每日T B I $0.2 \mathrm{~g}$ と PA S 8～10 g とを併用する.
刃 Ross ${ }^{55}$ は S M 1 日 $2 \mathrm{~g}$ と I NAH 250mg 毎日14日 使用し，次いでT B I 100〜 150mgとPAS 7 g 14日間 の交互使用安, Petkovićs ${ }^{52}$ はS M己PAS, SMとI NAH，PAS INAHと交互に使用している。

尚との他にS Mと Chaulmoogra 油を用いる人もあ $ろ^{20557)}$.

要するにて㣗等の方法は耐性の出現を極力抑えて, 副 作用を少くし，臨床效果を出來るだけあげるために用い られるものであつて, その人の好みの藥劑を使用するの は當然である. 從つて今後種々の藥劑が出現すれば，更 に色々な併用方法が行われるであるうし, 刃それによつ て治療は進歩するものと考えられる。

\section{III. 自家實驗}

\section{第 I 節 腎結核}

\section{A. 治療成績}

腎結核 155例に化學潦法安施行し, その尿所見, イン ヂゴカルミン排泄試驗, 腎孟像えの影響を觀察し，腎剔 除施行例については, その一部は化學療法の腎組織像に 及洔す影響を检索し, 腎組織像と臨床所見, 腎病變, 腎 内容及び結核菌の有無等の關係について觀察した。

(1) 症例

施行した化學療法により症例を分類し，手琎未施行例 そ腎剔除施行例に分けた (第 1 表).

これ等を性別，年齢別及び患側別に分類表示する（第 2,3 表).

（2）使用量

$\mathrm{S} \mathrm{M} 1$ 日 $1 \mathrm{~g}$ （毎12時間 $0.5 \mathrm{~g}$ ）筋肉内注射を行つ た. T B I は初め 1 日 $25 \mathrm{mg} 2 \sim 3$ 四に分服し, 副作 用のない場合は漸時増量し，100〜 200mgk及んだ。 P54はT B I に準じた。INAHは最初 5〜 7 日 100mg 次いで 200mg を1 日 3 回に分服したが, 副作用が少い ので最初より 300 略を用いた例もある. I HM S 泣最初 500〜 750mgを 1 日 3 四に分服し， $1 \mathrm{~g}$ に増量したが, 最初より $1 \mathrm{~g}$ 学使用した例もある.併用例については種 々の組合せで施行したので比較し得ない例もある，との 弓ち S M 0.5 g毎12時間筋注と毎日 PA S 10 g 使用を併 用 (1)とし，SM 1 g週 2 回筋注, 毎日 P A S $10 \mathrm{~g}$ 投與 を併用（2）として比較した。

(3) 尿所見

尿所見については使用前と使用後の尿の混濁, 蛋白, 白血球及び結核菌の變化について检索した結果は次の表 に示す（第 4 表a及びb.）. 
第 1 表 督結核患者各種化學療法施行例

\begin{tabular}{|c|c|c|c|c|c|c|c|}
\hline 症例 種類 & SM & TBI & P54 & INAH & IHMS & 併用例 & 計 \\
\hline 腎剔末施行例 & 5 & 11 & 5 & 20 & 9 & 23 & 73 \\
\hline 腎剔 除 例 & 15 & 14 & 1 & 18 & 10 & 24 & 82 \\
\hline 計 & 20 & 25 & 6 & 38 & 19 & 47 & 155 \\
\hline
\end{tabular}

第 2 表 性別・年路別

\begin{tabular}{|c|c|c|c|c|c|c|c|c|c|}
\hline 種 類 & 性 年齢 & $1 \sim 9$ & $10 \sim 19$ & $20 \sim 29$ & $30 \sim 39$ & $40 \sim 49$ & $50 \sim 59$ & $60 \sim$ & 合計 \\
\hline \multirow{2}{*}{ SM } & $\hat{o}$ & 0 & 2 & 5 & 6 & 0 & 0 & 0 & 13 \\
\hline & 우 & 0 & 0 & 5 & 0 & 2 & 0 & 0 & 7 \\
\hline \multirow{2}{*}{$\begin{array}{c}\text { TBI } \\
*(\text { P54) }\end{array}$} & $\hat{\delta}$ & 0 & 2 & $8(3)$ & $6(1)$ & 0 & 1 & 0 & $17(4)$ \\
\hline & 우 & 0 & 0 & $4(2)$ & 2 & 2 & 0 & 0 & $8(2)$ \\
\hline \multirow[b]{2}{*}{ INAH } & $\hat{o}$ & 0 & 4 & 5 & 10 & 2 & 2 & 0 & 23 \\
\hline & ㅇ & 0 & 3 & 6 & 4 & 2 & 0 & 0 & 15 \\
\hline \multirow{2}{*}{ IHMS } & $\hat{o}$ & 0 & 0 & 7 & 3 & 2 & 1 & 0 & 13 \\
\hline & 웅 & 0 & 0 & 2 & 2 & 2 & 0 & 0 & 6 \\
\hline \multirow{2}{*}{ 併用例 } & $\hat{o}$ & 0 & 1 & 8 & 5 & 5 & 0 & 0 & 19 \\
\hline & 우 & 0 & 4 & 9 & 7 & 2 & 4 & 0 & 26 \\
\hline
\end{tabular}

* カッニ內は P 54症例である.

第 3 表 腎結核の種類及び患側

\begin{tabular}{|c|c|c|c|c|c|c|c|c|}
\hline 疾患種類 & 患 側 & SM & TBI & P54 & INAH & IHMS & 併用例 & 合 \\
\hline \multirow[b]{2}{*}{1 側腎結核 } & 右 側 & 8 & 8 & 2 & 13 & 10 & 10 & 51 \\
\hline & 側 & 6 & 7 & 0 & 11 & 7 & 11 & 42 \\
\hline 兩腎結 核 & - & 4 & 3 & 3 & 5 & 2 & 17 & 34 \\
\hline \multirow{2}{*}{ 殘腎結核 } & 右 側 & 1 & 2 & 0 & 6 & 0 & 3 & 12 \\
\hline & 左 側 & 0 & 2 & 0 & 1 & 0 & 4 & 7 \\
\hline 督結核の疑 & \multirow[t]{2}{*}{-} & 1 & 3 & 1 & 2 & 0 & 2 & 9 \\
\hline 合 計 & & 20 & 25 & 6 & 38 & 19 & 47 & 155 \\
\hline
\end{tabular}

尿所見の全般的改善が現われるに要した $\mathrm{g}$ 數及び日數 について比較すると，SMは20 g 30g（20〜30日), T B I 以約 6 g ( 100 日前後) であるが不確實であり，I NAH注3 $6 \mathrm{~g}$ (15 30日), I HMS 日前後), 併用 (1)は20〜30日, 併用 (2)经40〜60日位で ある。

但しINAH，IHMSでは一眭改善した尿所見がが 再び惡化する場合定認める。恐らくこれ称耐性と關係が あるものと思われる。

尿所見の改善以 S M, 併用 (1), I NAH, I HM S

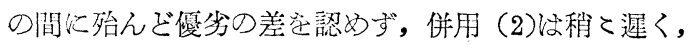

T B I, P54约明らかに効果が抢とつているものと考元 られる。

全症例を通じて尿所見の改善は一般に腎機能の良好
な，腎病巢の輕度の症例程顯著であつた。

(4) インデゴカルミン排泄試驗

$\mathrm{SM}$ 施行例では特に著明な影響は認しられなふつた

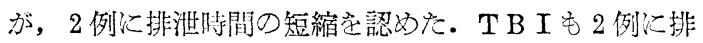
泄时間が稍乙短縮した。 しかし, INAHの 3 例, I H M Sの 3 例には著明な排泄時間の短縮が起つた. 併用 （2）では 5 例に著明な改善导認めている.改善の起つた日 數恬 S Mの40及び55日, I NAHの20 60日, I HMS の17 60日, 併用 (2)の40〜60日である.一般に比較的 長期の日數を型ずるものであるが，INAH，IHMS は粗く早く起るよろである。

（5）腎孟像に對する影響

SMは約20\%に改善を示すといわれているが，著者の 例では S M $33 \mathrm{~g}$ 使用例汇稍と改善を認めた程度で, T B 


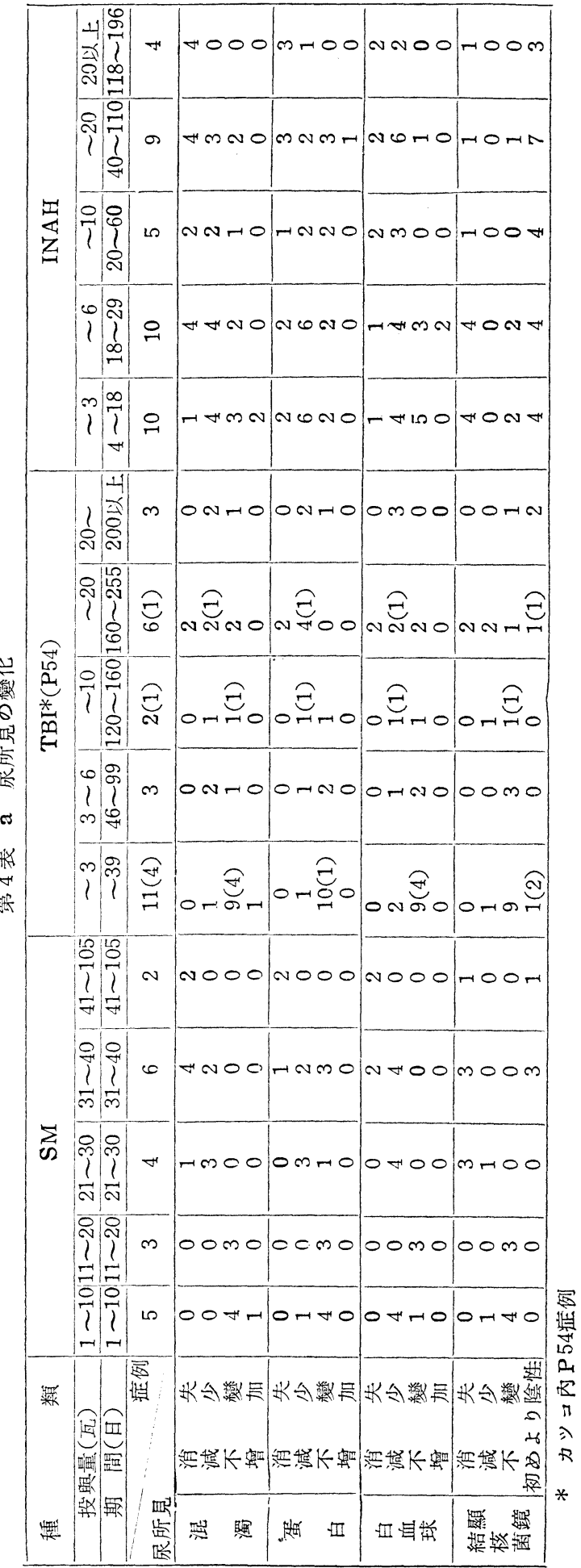

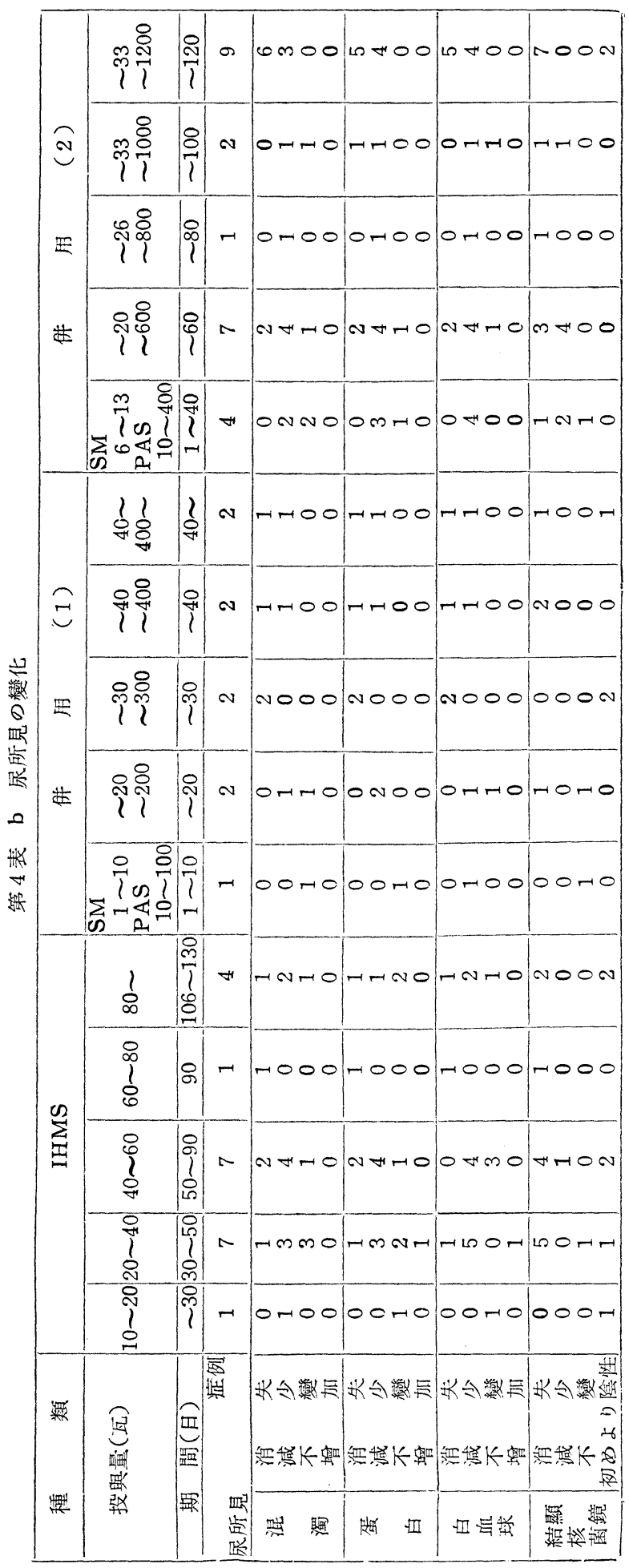


Iには改善例がなく，I NAHの60日使用例に 1 例, I HMS $の 60 〜 120$ 日使用例に 3 例の改善安認めた. 併用 例には比輍的改善例が多〉認められ，併用 (2) 飞 3 例,

$\mathrm{INAH}+\mathrm{SMK} 3$ 例, PAS + I HMSK 2 例の改善 例がある。これ等はいづれも60日以上の使用例であり， 病戀の輕度の症例のう5長期化學療法例飞多い。

（6）䝳組織像に及ぼす影響

腎結核がその侍期, 病型により非常な複雜な組織像を 示すとと裉に知られている。從つてその組織像に對す る化學療法の影響是判定するのは困難な點も少くない が, 未治療を對照として,これに認められない組織像 で，化學療法による影響と思われれる默を觀察した。

用いた標本は Haematoxylin-Eosin染色, Van Gieson染色, Azan 染色及び鍍銀法によるものである.

a) 腎些洞乃至腎潰瘍

(i) 未治療例 (弿真 1 )

對照の未治療例认潰瘍面认は厚く乾酪物質が附着し， 類上皮細胞層は乾酪物質え移行し, 銀好線維も壊死層内 えの移行が認められ，その間に明らかな區別が認められ ず，出性の周局炎が存在し，周圍には急性結核性病戀 が認められる場合も多い. 結核性肉芽内には毛細血管の 新生はない.

(ii) SM使用例 (寫真 2)

乾酪物質决潰瘍面の清浄化に從い水分学消失し，剥脱 して少く成つて行く. S M $15 \mathrm{~g}$ 使用で乾酪物質の剥脱空 認め, 空洞壁の清浄化が起る. 15 20g 使用せるもので 清浄化された例にはその空洞表面に上皮再生の認められ るものがあり, $30 \mathrm{~g}$ 以上の例ではそれが眉と認められ る. 類上皮細胞層は $15 \mathrm{~g}$ 以上使用例で著明な萎縮が見ら れ，類上皮細胞層が薄く成り，巨細胞も菱縮變形して定 型的な Langhans 氏巨細胞の型を失う例む多い. 周圍 の疹出性炎症の停止, 周局炎の消迟は $5 \sim 10 \mathrm{~g} て ゙$ 起り明 膫な膠原線維の分劃は形成されず，或る程度以上の使用

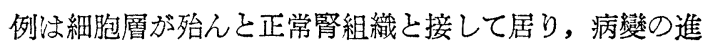
展注停止している。結核性肉芽内に血管の新生を認める 例もある。

(iii) T B I使用例（舁真 3 )

SM c同様江空洞壁の乾酪物質认, 表面の清浄化に從 い減少してくるが，乙れが明らかに成るのは 4.35 g（99 日) 使用啳の例で, 清浄化に伴い一部に上皮の再生が起 る. 上述の例より上皮再生が起つているが, $8.1 \mathrm{~g}$ (110 日）位使用した例で明ら吕に成る. 類上皮細胞層も菱縮 するが，これは $2.05 \mathrm{~g}$ (50日) 使用の例で認められ，
$4.53 \mathrm{~g}$ 或はそれ以上の例で明らかに成るがSMに比して 弱い. 類上皮細胞, 巨細胞も萎縮する.膠原線維の分劃 形成は試められない，病戀周圍の邆出性の炎症の消退は $2 \mathrm{~g}$ (38日) の例認められる。しかし，5.2g(46日) 使用例で䢧出性炎症の消退しない例も認められ，SMに 比して非常に効果が弱いものと思われる。

(iv) I NAH使用例（寫真4,5）

本劑も腎盕と交通ある空洞は, 乾酪物質の減少と表面 の清浄化を起す２.5 g (15日) 使用で清浄化が認めら れ, 清浄化された潰湯面には $3.5 \mathrm{~g}$ (30日).で上皮再生 を認めた例もあるが, 確賽に成るのは $4.5 \mathrm{~g}$ 以上の使用 例である. 類上皮細胞層の菱縮空洞化は $0.5 \mathrm{~g}$ （5日） 使用例で既に起り初め, $2.5 \mathrm{~g}$ (15日) 以上の使用で著 明に成る. 巨細胞も萎縮するが類上皮細胞より遲く, 類 上皮細胞消失後も残存する. 又明膫な膠原線維の形成は 認められず, 炎症性出は $1.5 \mathrm{~g}$ (10日) の使用で消退 する. 結核性肉芽組織内え著明な血管新生を認める例も ある。

(v) I HM S 使用例（舁真 6,7 )

I HM S 15 g（20日）で乾酪物質の剝脱, 空洞表面の 清浄化が起り, 且つ上皮の再生を認めた例もあるが, 清 浄化と上皮再生が確實に或るのは48 g (48日) 以上であ つた. 類上皮細胞層の萎縮, 空洞化も15g (20日) で起 り，周局炎も消退している. 恐らく本劑と I NAH この 間には本質的には差がなく，もしあるとしても多分量的 なものと考えられる。

b）腎實質内の結核結節

(i) 未使用例

結核結節は類上皮細胞結節と中心に乾酪巢を有するも のとがある.乙记等の結節中の類上皮細胞及び巨細胞は 多くは定型的であり, 周園には著明な周局炎の存在する 場合が多い，結節の銀好線維の狀態は種々であり，慢性 化定示した場合は比較的多い.

(ii) S M使用例（舁真 8)

結核結節の周局炎は $10 \mathrm{~g}$ 位で消退し，15g使用例では その類上皮細胞が萎縮し,やせた狀態になり,原形質も狭 く成る. 類上皮細胞結節は全體として粗に成り萎縮, 縮 小する. 巨細胞も定型的な Langhans 氏型学とらなく 成る.結節内の銀好線維の増殖注認められず，周圍の翏 原線維つ被罴形成も見られない。結節内の乾酪物質は乾 燥固化し, $20 \mathrm{~g}$ 以上の例法乾酪物質内に不規則な間隙を 生じ, 時に壊死前の構造を示すものがあり, 周圍より淋 
第 5 表 剔除腎組織に及ぼす影響その他

a. SM.

\begin{tabular}{|c|c|c|c|c|c|c|c|c|c|c|c|c|c|c|c|c|c|c|c|c|c|}
\hline \multirow[b]{2}{*}{ 姓 名 } & \multirow[b]{2}{*}{$\begin{array}{l}\text { 性 } \\
\text { 別 } \\
\dot{\text { 年 }} \\
\text { 龄 }\end{array}$} & \multirow[b]{2}{*}{$\begin{array}{l}\text { 患 } \\
\text { 側 }\end{array}$} & \multirow[b]{2}{*}{$\begin{array}{l}\text { 使合 } \\
\text { 用 } \\
\text { 量數 }\end{array}$} & \multirow[b]{2}{*}{$\begin{array}{l}\text { I.P. } \\
20 \text { 分 } \\
\text { 排泄 }\end{array}$} & \multirow[b]{2}{*}{$\begin{array}{l}1 \text { 排 } \\
2 \\
\text { ヂ } \\
\text { ב泄 }\end{array}$} & \multicolumn{2}{|r|}{ 空 } & \multicolumn{3}{|c|}{ 洞壁 } & \multicolumn{3}{|c|}{$\begin{array}{l}\text { 腎實質內 } \\
\text { 結核結笽 }\end{array}$} & \multirow[b]{2}{*}{$\begin{array}{l}\text { 效 } \\
\text { 果 }\end{array}$} & \multirow[b]{2}{*}{$\left|\begin{array}{l}\text { 剔重 } \\
\text { 除量 } \\
\text { 腎 } \\
\mathbf{g}\end{array}\right|$} & \multirow[b]{2}{*}{$\begin{array}{l}\text { 病 } \\
\text { 變 }\end{array}$} & \multirow[b]{2}{*}{$\begin{array}{l}\text { 空肉 } \\
\text { 洞眼 } \\
\text { 容的 } \\
\text { 管 }\end{array}$} & \multirow[b]{2}{*}{$\begin{array}{l}\text { 同菌 } \\
\text { 左顯 } \\
\text { 結 } \\
\text { 核 }\end{array}$} & \multirow[b]{2}{*}{$\begin{array}{l}\text { 同菌 } \\
\text { 左培 } \\
\text { 結 } \\
\text { 核 }\end{array}$} & \multirow[b]{2}{*}{$\begin{array}{l}\text { 剔中 } \\
\text { 除白 } \\
\text { 前 血 } \\
\text { 尿球 }\end{array}$} & \multirow[b]{2}{*}{ 请 考 } \\
\hline & & & & & & $\begin{array}{l}\text { 乾 } \\
\text { 酪 } \\
\text { 物 } \\
\text { 質 }\end{array}$ & $\begin{array}{l}\text { 淸 } \\
\text { 淨 } \\
\text { 化 }\end{array}$ & $\begin{array}{l}\text { 上 } \\
\text { 皮 } \\
\text { 再 } \\
\text { 生 }\end{array}$ & 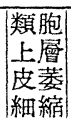 & $\begin{array}{l}\text { 周 } \\
\text { 局 } \\
\text { 炎 }\end{array}$ & $\begin{array}{l}\text { 周 } \\
\text { 局 } \\
\text { 炎 }\end{array}$ & \begin{tabular}{|} 
上類胞 \\
上萎樎 \\
細
\end{tabular} & $\left|\begin{array}{l}\text { 新結 } \\
\mathrm{L} \\
\text { 篩 }\end{array}\right|$ & & & & & & & & \\
\hline 1. 小○ & $\begin{array}{c}21 \\
\hat{\delta}\end{array}$ & $\begin{array}{c}\text { 雨 } \\
\text { (右) }\end{array}$ & $\begin{array}{l}94 \mathrm{~g} \\
(94)\end{array}$ & 無 & 無 & - & $H$ & $H$ & + & - & - & $H$ & - & $H$ & 175 & IV & \begin{tabular}{|l|} 
黄色 \\
水樣
\end{tabular} & $\mathrm{H}$ & + & + & $\begin{array}{l}\text { TBI } 2.5 \\
\mathrm{~g} \text { 併用 }\end{array}$ \\
\hline 2. 岡 $\bigcirc$ & $\begin{array}{c}16 \\
\text { o }\end{array}$ & 右 & $\begin{array}{l}46 \mathrm{~g} \\
(46)\end{array}$ & - & 不良 & - & $H$ & + & + & - & - & $H$ & - & + & 130 & II & 黃色 & + & + & + & $\begin{array}{l}\text { TBI } 4.5 \\
\mathrm{~g} \text { 併用 }\end{array}$ \\
\hline 3. 遠O & $\begin{array}{l}26 \\
\hat{\delta}\end{array}$ & 左. & $\begin{array}{l}42 \mathrm{~g} \\
(42)\end{array}$ & 無 & 無 & $\mathrm{HH}$ & - & - & $H$ & \pm & & & & \pm & 350 & IV & 膿樣 & $\mathrm{HH}$ & $H$ & \pm & \\
\hline 4. 笛 & $\begin{array}{l}35 \\
0 \\
\end{array}$ & 右 & $\begin{array}{l}37 \mathrm{~g} \\
(37)\end{array}$ & 不良 & 淞 & $H$ & \pm & - & + & - & - & $H$ & - & + & 260 & IV & 黄色 & \pm & - & \pm & \\
\hline 5. 高 $\mathrm{O}$ & $\begin{array}{c}35 \\
\hat{0}\end{array}$ & 右 & $\begin{array}{l}33 \mathrm{~g} \\
(33)\end{array}$ & 無 & 無 & + & $H$ & $H$ & $H$ & - & - & + & - & + & 340 & IV & 膿様 & $H$ & $H$ & + & \\
\hline 6. 松O & $\begin{array}{c}23 \\
\delta \\
\end{array}$ & 左 & $\begin{array}{l}30 \mathbf{g} \\
(30)\end{array}$ & 無 & 無 & 册 & - & - & + & \pm & \pm & \pm & - & \pm & 610 & IV & 膿樣 & $\mathrm{HH}$ & $\mathrm{HH}$ & - & 閉塞 \\
\hline 7. 柳O & $\begin{array}{c}22 \\
q\end{array}$ & 右 & $\begin{array}{l}28 \mathbf{g} \\
(28)\end{array}$ & 良好 & 正常 & - & $\mathrm{HH}$ & H & H & - & - & $\mathrm{HH}$ & - & $H$ & 145 & II & 水栐 & + & + & - & \\
\hline 8. 藤 $\bigcirc$ & $\begin{array}{l}23 \\
\text { ㅇ }\end{array}$ & 右 & $\begin{array}{l}26 \mathrm{~g} \\
(26)\end{array}$ & \begin{tabular}{|l} 
稍了 \\
不良
\end{tabular} & 稍了 & - & + & + & H & - & - & $\mathrm{HH}$ & - & $H$ & 170 & III & 水樣 & $H$ & - & - & \\
\hline 9. 和 $\bigcirc$ & $\begin{array}{l}40 \\
9\end{array}$ & 右 & $\begin{array}{r}15 \mathrm{~g} \\
(15) \\
\end{array}$ & - & 稍了 & - & + & + & HH & - & - & $H$ & - & + & 140 & II & 水樣 & + & + & \pm & \\
\hline 10. 田 $\bigcirc$ & $\begin{array}{c}27 \\
\hat{\delta} \\
\end{array}$ & 右 & $\begin{array}{l}12 \mathbf{g} \\
(12) \\
\end{array}$ & 不良 & 無 & $H$ & + & + & - & \pm & & & & \pm & 125 & III & \begin{tabular}{|} 
黄色 \\
水樣
\end{tabular} & + & + & + & \\
\hline 11. 丸O & $\begin{array}{c}37 \\
\hat{0}\end{array}$ & 右 & $\begin{array}{l}10 \mathrm{~g} \\
(10) \\
\end{array}$ & 良好 & 正常 & $H$ & - & - & \pm & - & - & + & - & \pm & 160 & IV & 膿樣 & $H$ & $H$ & $H$ & \\
\hline 12. 筑 $\bigcirc$ & $\begin{array}{l}19 \\
\hat{\delta}\end{array}$ & 左 & \begin{tabular}{|c|}
$6 \mathrm{~g}$ \\
$(6)$ \\
\end{tabular} & 不良 & 無 & $\mathrm{HH}$ & - & - & + & + & & & & - & 291 & IV & 膿樣 & $\mathrm{HH}$ & H & $H$ & \\
\hline 13. 井○ & $\begin{array}{l}41 \\
9 \\
\end{array}$ & 左 & $\left.\mid \begin{array}{ll}2 & g \\
(2 & 2\end{array}\right)$ & 無 & 無 & $\mathrm{HH}$ & - & - & - & + & + & - & - & - & 70 & III & 膿樣 & H & H & $H$ & \\
\hline 14. 高 $\bigcirc$ & $\begin{array}{c}18 \\
\delta\end{array}$ & 右 & $\mid \begin{array}{l}60 \mathrm{~g} \\
(60)\end{array}$ & 不良 & 無 & - & $\mathrm{HH}$ & H & H & - & - & HH & - & $\mathrm{HH}$ & 150 & III & 膿樣 & + & $H$ & $H$ & \\
\hline 15. 大○ & $\begin{array}{c}25 \\
\hat{\delta} \\
\end{array}$ & 右 & $\left|\begin{array}{l}32 \mathrm{~g} \\
(32)\end{array}\right|$ & - & \begin{tabular}{|l|} 
秒 \\
不良 \\
\end{tabular} & - & $\mathrm{HH}$ & $\mathrm{HH}$ & + & - & - & $\mathrm{HH}$ & - & $\mathrm{HH}$ & 150 & III & 膿樣 & + & $\mathrm{H}$ & $H$ & \\
\hline 16. 塩 $\bigcirc$ & $\begin{array}{c}25 \\
\hat{\delta}\end{array}$ & 左 & $\left|\begin{array}{l}23 \mathbf{g} \\
(23)\end{array}\right|$ & - & 正常 & - & $\mathrm{HH}$ & + & HH & - & - & $\mathrm{HH}$ & - & $\mathrm{HH}$ & 145 & II & 膿様 & + & $H$ & \pm & \\
\hline 17. 山○ & $\begin{array}{c}23 \\
\hat{0}\end{array}$ & 右 & $\left|\begin{array}{l}10 \mathrm{~g} \\
(10)\end{array}\right|$ & 不良 & 無 & \pm & - & - & - & \pm & \pm & \pm & - & - & 390 & IV & 膿栐 & $H$ & $\mathrm{HH}$ & $\mathrm{HH}$ & \\
\hline
\end{tabular}

註：1－13迄は剔除直前使用例，14〜17迄は剔除前數カ月の間に使用

巴球の侵入を見る。

(iii) T B I使用例

或る程度使用した例では周局炎の消退を認めるが， $\mathrm{S}$ M程顯著でない。しかしその類上皮細胞及びE細胞にも 萎縮する傾向は認められる。結核結節も縮小の傾向学認 めるが，しばしば同一標本内にも縮小しない結節が混在 するも例ある・結節周圍の膠原線維の被絧形成は明かて ないが，長期の使用により周圍えの進展傾向はなくなる ものと考えられる. しかしSMに比してその程度は極め て弱いものと考えられる。 (iv) I NAH使用例（寫真 9)

周局炎は $0.5 \mathrm{~g}$ (5日) で減退し， $1 \mathrm{~g}$ (10日) 以上 では殆んぞ認められない. 類上皮細胞の菱縮, 空泡形成 は $0.5 \mathrm{~g} て ゙$ 起りはじめ, $1.5 \mathrm{~g}$ (15日) の使用量で顯著 に成る．2３g（20日）以上の例では類上皮細胞の消 退して行く像が㷫められる.しかし巨細胞经残存してい る. 乾酪㭴の修理反碓は S M と同様である.

(v) I HMS 使用例 (弿真10)

周局炎は添とんど全症例に消失して居り,類上皮細胞, 巨細胞の菱縮も大體全症例仁認められる。乙れ等の點に 
第 5 表 b. TBI 及び P54

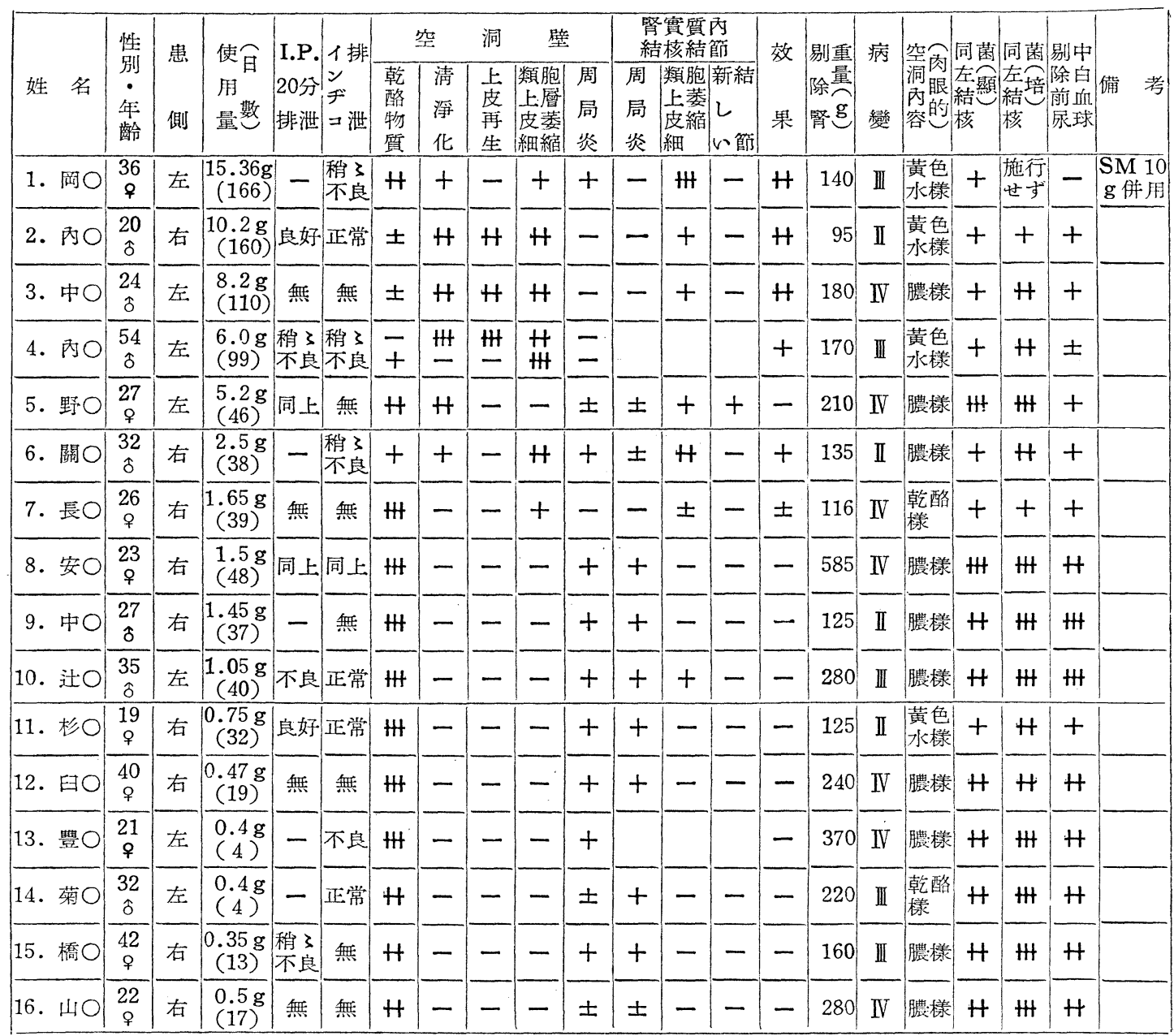

註 16 \&54使用例

關しては I NAH例と全く同様であり，周圍の膠原線維 も認められない。

小括 : 以上の影響空空洞壁, 腎實質に分け, 空洞壁て は然洞表面の乾酪物質の存在, 清浄化, 上皮再生, 類上 皮細胞層の萎縮, 翏出性周局炎の存在について, 腎實質 内結核結節については周局炎の存在, 類上皮細胞の萎 縮, 新しい結節の新生等について表示する（第 5 表 $a$ d).

\section{（7）剔除腎機能及び病變}

剔除腎の機能について，インデゴカルミン排泄試驗の 排泄時間と静脈性腎孟像 (I.P.) により, これを比較し て見た。
インデゴカルミン排泄は，その排泄時間により正常， 稍々不良, 不良, 無の 4 つに分け, I.P.について山注 射後 20 分の排泄像について良好, 稍と不良, 不良, 無已 に分けた (第 5 表).

次に剔除腎の病戀学 Lattimerの分類 ${ }^{34)}$ にり 0 〜 群に分けた。即与0群は小病巢といわれる腎孟像に病變 の認められないもので腎尿に結核菌陽性群, I 群は腎尿 に結核菌陽性で腎盂像に輕微な變化があり腎杯の破壊の 疑ある例. II 群は 1 個の督杯江破壊像あり, 結核菌陽性 例, I 及び II 群は刃中病巢ともいわれる。III群は 2 個の 腎杯が結核性の破壊を示す例. IV 群は 3 個以上の腎杯の 結核性破壊它示す例であり，四及びIV群は大病巢といわ れる。てれ等により上述の組織像えの影響を比較するた 
第 5 表 c. INAH

\begin{tabular}{|c|c|c|c|c|c|c|c|c|c|c|c|c|c|c|c|c|c|c|c|c|c|}
\hline \multirow[b]{2}{*}{ 姓 名 } & \multirow[b]{2}{*}{$\begin{array}{l}\text { 性 } \\
\text { 別 } \\
\text { 年 } \\
\text { 齡 }\end{array}$} & & \multirow[b]{2}{*}{$\begin{array}{l}\text { 使用量 } \\
(\text { 數) }\end{array}$} & \multirow[b]{2}{*}{$\begin{array}{l}\text { I.P. } \\
20 \text { 分 } \\
\text { 排泄 }\end{array}$} & \multirow[b]{2}{*}{$\mid \begin{array}{l}1 \text { 排 } \\
\text { 年 } \\
\text { ヂ } \\
\text { ゴ泄 }\end{array}$} & \multicolumn{3}{|c|}{ 空 } & \multicolumn{2}{|c|}{ 洞＼cjkstart壁 } & \multicolumn{3}{|c|}{$\begin{array}{l}\text { 堅實啠內 } \\
\text { 結核結篩 }\end{array}$} & \multirow[b]{2}{*}{$\begin{array}{l}\text { 效 } \\
\text { 果 }\end{array}$} & \multirow[b]{2}{*}{$\begin{array}{l}\text { 剔重 } \\
\text { 阵 } \\
\text { 腎量 }\end{array}$} & \multirow{2}{*}{$\begin{array}{l}\text { 病 } \\
\text { 變 }\end{array}$} & \multirow{2}{*}{ 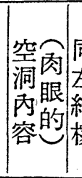 } & \multirow{2}{*}{\begin{tabular}{l|l} 
同菌 \\
左影 \\
核
\end{tabular}} & \multirow{2}{*}{ 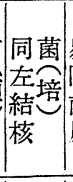 } & \multirow{2}{*}{ 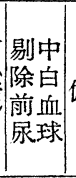 } & \multirow{2}{*}{ 備 考 } \\
\hline & & & & & & $\begin{array}{l}\text { 榦 } \\
\text { 酪 } \\
\text { 物 } \\
\text { 質 } \\
\end{array}$ & $\begin{array}{l}\text { 清 } \\
\text { 淨 } \\
\text { 化 }\end{array}$ & $\begin{array}{l}\text { 在 } \\
\text { 再 } \\
\text { 生 }\end{array}$ & 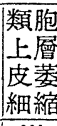 & $\begin{array}{l}\text { 周 } \\
\text { 局 } \\
\text { 炎 }\end{array}$ & $\begin{array}{l}\text { 周 } \\
\text { 局 } \\
\text { 炎 } \\
\end{array}$ & 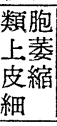 & $\begin{array}{l}\text { 新結 } \\
\text { L } \\
\text { 、䇫 } \\
\end{array}$ & & & & & & & & \\
\hline 1. 石 $\bigcirc$ & $\begin{array}{c}17 \\
0 \\
\end{array}$ & 右 & $\begin{array}{c}24.5 \mathrm{~g} \\
(118)\end{array}$ & 稍了 & 正常 & $\bar{t}$ & + +m & 两 & $\begin{array}{ll}\text { H } \\
\text { H } \\
\end{array}$ & $\overline{-}$ & - & $H$ & - & $\mathrm{H}$ & 165 & II & 水樣 & - & - & -5 & $\mathrm{M}_{20}$ \\
\hline 2. 片O & $\begin{array}{l}39 \\
0 \\
\end{array}$ & 右 & $\begin{array}{l}14.65 \mathrm{~g} \\
(90)\end{array}$ & 正常 & 正常 & + & - & - & $\mathrm{H}$ & - & & & & $H$ & 135 & III & 膿樣| & + & + & \pm & \\
\hline 3. 鶴O & $\begin{array}{l}34 \\
\hat{0} \\
\end{array}$ & 右 & $\begin{array}{l}14.3 \mathrm{~g} \\
(80)\end{array}$ & 無 & 不良 & + & $H$ & + & $H$ & \pm & - & $H$ & - & \pm & 200 & IV & 黄色 & - & - & - & \\
\hline 4. 鈴O & $\begin{array}{l}37 \\
\mathbf{+} \\
\end{array}$ & 右 & $\begin{array}{l}13.75 \mathrm{~g} \\
(70)\end{array}$ & 無 & 無 & $H$ & \pm & - & $H$ & - & - & + & - & \pm & 105 & III & 血性 & + & + & \pm & \\
\hline 5. 田○ & $\begin{array}{c}23 \\
9 \\
\end{array}$ & 左 & $\begin{array}{l}7.0 \mathrm{~g} \\
(32) \\
\end{array}$ & 不良 & 無 & $\begin{array}{l}H \\
\pm\end{array}$ & $\bar{H}$ & $\bar{H}$ & H & $\overline{-}$ & - & $H$ & - & $H$ & 180 & III & 血性 & + & + & \pm & \\
\hline 6. 今० & $\begin{array}{c}21 \\
\hat{0}\end{array}$ & 右 & $\begin{array}{l}6.8 \mathrm{~g} \\
(31)\end{array}$ & 不良 & 無 & + & \pm & \pm & $H$ & - & - & $H$ & - & + & 300 & IV & 膿䂿 & + & $H$ & + & \\
\hline 7. 大O & $\begin{array}{l}53 \\
\hat{0} \\
\end{array}$ & 右 & $\begin{array}{l}5.25 \mathrm{~g} \\
(36) \\
\end{array}$ & 稍了 & 正常 & + & - & - & + & \pm & \pm & + & - & \pm & 160 & III & 黄色 & + & \begin{tabular}{|l|} 
施行 \\
せずす
\end{tabular} & - & \\
\hline 8. 荒O & $\begin{array}{c}17 \\
\hat{\delta} \\
\end{array}$ & 左 & $\begin{array}{l}5.0 \mathrm{~g} \\
(20) \\
\end{array}$ & 無 & 無 & $\mathrm{WH}$ & - & - & $\mathrm{HH}$ & - & \pm & + & - & \pm & 220 & IV & 膿樣| & + & $\mathrm{HH}$ & $H$ & \\
\hline 9. 淺○ & $\begin{array}{c}36 \\
+ \\
\end{array}$ & 左 & $\begin{array}{l}4.5 \mathrm{~g} \\
(26) \\
\end{array}$ & 不良 & 無 & $\stackrel{+}{H}$ & $\begin{array}{l}+ \\
\pm\end{array}$ & \pm & H & $\overline{-}$ & - & + & - & + & 170 & III & 膿樣| & + & $H$ & + & \\
\hline 10. 宮O & $\begin{array}{c}19 \\
\hat{\delta} \\
\end{array}$ & 左 & $\begin{array}{l}4.4 \mathrm{~g} \\
(29) \\
\end{array}$ & 不良 & 無 & $H$ & \pm & - & $H$ & - & - & + & - & \pm & 400 & IV & 膿樣 & $H$ & + & + & \\
\hline 11. 染O & $\begin{array}{l}21 \\
\hat{0} \\
\end{array}$ & 右 & $\begin{array}{l}3.5 \mathrm{~g} \\
(30) \\
\end{array}$ & - & \begin{tabular}{|l|} 
㮐了良 \\
\end{tabular} & + & $H$ & $H$ & $\mathrm{H}$ & - & - & $H$ & - & $H$ & 180 & III & \begin{tabular}{|l} 
黄色 \\
水樣 \\
\end{tabular} & + & + & \pm & \\
\hline 12. 溝O| & $\begin{array}{l}47 \\
0\end{array}$ & 左 & $\begin{array}{l}2.5 \mathrm{~g} \\
(15)\end{array}$ & 不良 & 正常 & + & $H$ & - & $H$ & - & - & $H$ & - & + & 150 & III & | & + & + & + & \\
\hline 13. 本O & $\begin{array}{l}26 \\
\hat{8} \\
\end{array}$ & 右 & $\begin{array}{l}2.0 \mathrm{~g} \\
(20) \\
\end{array}$ & 無 & 無 & H & - & - & \pm & + & - & - & - & - & 490 & IV & 膿樣 & $\mathrm{HH}$ & $\mathrm{HH}$ & $H$ & \\
\hline 14. 針○ & $\begin{array}{c}18 \\
+ \\
\end{array}$ & 左 & $\begin{array}{l}1.7 \mathrm{~g} \\
(18) \\
\end{array}$ & 無 & 無 & HH & - & - & \pm & - & - & \pm & - & - & 160 & III & 膿㭼 & $H$ & $H$ & + & \\
\hline 15. 黑O & $\begin{array}{l}27 \\
\hat{\delta} \\
\end{array}$ & 左 & $\begin{array}{l}1.5 \mathrm{~g} \\
(10) \\
\end{array}$ & \begin{tabular}{|l|} 
㮐了 \\
\end{tabular} & 稍了 & + & - & - & + & - & - & + & - & \pm & 170 & III & 膿樣| & + & + & + & \\
\hline 16. 床O & $\begin{array}{c}23 \\
9 \\
\end{array}$ & 右 & $\begin{array}{l}0.7 \mathrm{~g} \\
(8)^{2} \\
\end{array}$ & 無 & 無 & \pm & - & - & \pm & \pm & \pm & \pm & - & - & 190 & IV & 䐕冁| & $H$ & $H$ & $H$ & \\
\hline 7. 鍋O| & $\begin{array}{l}25 \\
\hat{\delta} \\
\end{array}$ & \pm & $\begin{array}{l}0.7 \mathrm{~g} \\
(7) \\
\end{array}$ & 正常 & 正常 & \pm & - & - & + & + & + & \pm & - & - & $\begin{array}{l}\text { 部分的 } \\
\text { 㹂剔除 }\end{array}$ & - & - & + & + & \pm & \\
\hline 8. 森O & $\begin{array}{c}25 \\
\hat{3} \\
\end{array}$ & 右 & {$\left[\begin{array}{l}0.5 \mathrm{~g} \\
(5)\end{array}\right.$} & 無 & 無 & $H$ & - & - & + & \pm & + & \pm & - & 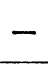 & 200 & $\mathbb{N}$ & 膿橉| & $H$ & $H$ & $H$ & \\
\hline
\end{tabular}

めに第 5 表沶守.

（8）惄空洞内容，空洞内結核菌の有無，培養成績， 剔除直前の尿中の白血球.

剔除せる腎臓の空洞内容, 空洞内容中の結核菌の有 無，培養成績を檢索した結果を同じく第 5 表に示す.

第 5 表学見ると，腎剔除琎施行例であるから勿論 0 群 は存在しないし, 又I群も存在せず，II一IV群に屬して いる. 次にてれ等を比輘检討する。

a) 腎組織に及ぼす影響

すべての抗結核劑が効果を示すには，腎病巢が輕度の
場合に著明である．例えばサ群の症例では比較的多量の 抗結核劑使用にもか>わらず，一般に充分な効果が組織 像に表われない.しかしII群に屬する症例は空洞壁の清 浄化, 上皮再生, 類上皮細胞の萎縮を認める場合が多 い. ヌインデゴカルミン，I.P.の排泄による腎機能检查 て，腎機能が比較的良好に保持されていると思われる症 例では，上述の變化が明らかである，從つて腎病變が高 度となり，腎機能が低下すれば，化學療法は奏効し難く 成る. 即ちこのょうな症例では抗結核劑が病戀部に透 しないためであろう．著者及び石山は S MKついて，教 
第 5 表. d. IHMS

\begin{tabular}{|c|c|c|c|c|c|c|c|c|c|c|c|c|c|c|c|c|c|c|c|}
\hline 姓性患 & & I.P. & 1排 & & 空 & 洞 & 壁 & & & 實質 & & 效 & 剔重 & 病 & & 同菌| & |同菌 & 剔中 & \\
\hline 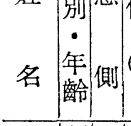 & (使用量 & 排泄 & 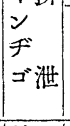 & $\begin{array}{l}\text { 幹 } \\
\text { 酪 } \\
\text { 質 } \\
\end{array}$ & $\begin{array}{l}\text { 清 } \\
\text { 淨 } \\
\text { 化 }\end{array}$ & \begin{tabular}{|l|} 
上 \\
皮 \\
再 \\
生
\end{tabular} & $\begin{array}{l}\text { 類胞 } \\
\text { 上顱 } \\
\text { 細縮 }\end{array}$ & $\begin{array}{l}\text { 周 } \\
\text { 局 } \\
\text { 炎 } \\
\end{array}$ & 周 & 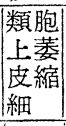 & 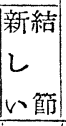 & 果 & $\begin{array}{l}\text { 除量 } \\
\text { 督总 }\end{array}$ & & 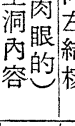 & $\begin{array}{l}\text { 左 } \\
\text { 結顯 } \\
\text { 核 }\end{array}$ & $\begin{array}{l}\text { 灰培 } \\
\text { 結境 } \\
\text { 核 }\end{array}$ & $\mid$ & 考 \\
\hline $\begin{array}{lll}1 . & 44 \\
9 & \text { 右 } \\
\end{array}$ & $\begin{array}{l}132 \mathrm{~g} \\
(140) \\
\end{array}$ & 良好 & |稍了 & \pm & $\mathrm{H}$ & $\mathrm{HH}$ & $\mathrm{HH}$ & - & - & $\mathrm{HH}$ & - & $\mathrm{HH}$ & 150 & III & 水栐 $\mid$ & - & - & - & \\
\hline $\begin{array}{ccc}2 . & 22 \\
& & \\
\end{array}$ & $\begin{array}{l}95 \mathrm{~g} \\
(180) \\
\end{array}$ & 不良 & 無 & + & $H$ & + & $\mathrm{H}$ & - & - & $H$ & - & $H$ & 140 & $\mathbb{I I}$ & \begin{tabular}{|l|} 
\\
黃色樽 \\
\end{tabular} & $H$ & + & + & \begin{tabular}{|l} 
PAS $1,328 \mathrm{~g}$ \\
併用 \\
\end{tabular} \\
\hline $\begin{array}{ccc}3 . & 20 \\
\end{array}$ & $\begin{array}{l}62 \mathbf{g} \\
(90) \\
\end{array}$ & 良好 & 正常 & \pm & $\mathrm{H}$ & H & $\mathrm{H}$ & - & - & H & - & $\mathrm{H}$ & 160 & III & 黃色 & $H$ & - & \pm & \\
\hline $\begin{array}{ccc}4 . & 41 \\
\end{array}$ & $\begin{array}{l}51 \mathrm{~g} \\
(51) \\
\end{array}$ & 不良 & 不良 & + & + & + & + & - & - & + & - & + & 270 & IV & \begin{tabular}{|l} 
黄色 \\
水栐
\end{tabular} & + & + & + & $\begin{array}{l}\text { SM } 3 \mathrm{~g} \\
\mathrm{PAS} 60 \mathrm{~g} \text { 併用 }\end{array}$ \\
\hline \begin{tabular}{c|c|}
5. & 28 \\
加 & \\
\end{tabular} & $\begin{array}{l}49 g \\
(49)\end{array}$ & 不良 & 無 & \pm & $H$ & + & $\mathrm{H}$ & - & - & $H$ & - & $H$ & 320 & IN & $\mid$ & $H$ & + & + & \\
\hline \begin{tabular}{|l|c|c|}
6. & 30 \\
& & 植 \\
\end{tabular} & $\begin{array}{l}48 \mathrm{~g} \\
(48) \\
\end{array}$ & 稍々 & 稍了 & + & + & + & $\mathrm{H}$ & - & - & $\mathrm{H}$ & - & $H$ & 315 & IV & \begin{tabular}{|l}
$\mid$ 黃色 \\
水樣 \\
\end{tabular} & + & + & \pm & \\
\hline $\begin{array}{ccc}\text { 春方 } & 38 \\
\end{array}$ & $\begin{array}{l}46 \mathrm{~g} \\
(46) \\
\end{array}$ & 不良 & 無 & + & + & - & $\mathrm{H}$ & - & - & - & - & + & 410 & IV & 黄色 & $H$ & $H$ & $H$ & $\begin{array}{l}\text { SM, PAS, TBI } \\
\text { 併用 }\end{array}$ \\
\hline $\begin{array}{r}8 . \\
\text { 大0 } \\
\end{array}$ & $\begin{array}{l}46 \mathrm{~g} \\
(49) \\
\end{array}$ & 不良 & 無 & + & + & + & $H$ & - & - & + & - & + & 380 & IV & |膿樣| & $H$ & $H$ & + & \\
\hline $\begin{array}{ll}9 & 23 \\
9 & \text { 右 } \\
\end{array}$ & $\begin{array}{l}26.5 \mathrm{~g} \\
(36) \\
\end{array}$ & 不良 & 無 & + & - & - & + & - & - & + & - & \pm & 165 & IV & 膿㯢| & + & $H$ & + & INAH $2.1 \mathrm{~g}$ 後 \\
\hline $\begin{array}{|lll|}10 . & 43 & \text { 瀨 } \\
\end{array}$ & $\begin{array}{r}26.2 \mathrm{~g} \\
(28) \\
\end{array}$ & 不良 & 不良 & + & + & + & + & - & - & $H$ & - & $H$ & 170 & III & 膿樣| & + & + & \pm & \\
\hline \begin{tabular}{|l|l|l|}
11. & 25 \\
吉 & 考 \\
\end{tabular} & $\begin{array}{l}24 \mathrm{~g} \\
(24) \\
\end{array}$ & 良好 & 不良 & + & \pm & - & $H$ & - & - & + & - & + & 200 & III & |嘈桠| & $H$ & + & \pm & \\
\hline \begin{tabular}{|l|l|l}
12. & 53 \\
\end{tabular} & $\begin{array}{l}19 \mathbf{g} \\
(19) \\
\end{array}$ & 不良 & 無 & + & - & - & + & - & - & + & - & \pm & 135 & IV & |膿樣 & + & + & + & PAS $190 \mathrm{~g}$ 併用 \\
\hline \begin{tabular}{|l|l|}
13. & 12 \\
& 右 \\
\end{tabular} & $\begin{array}{l}16 \mathrm{~g} \\
(40) \\
\end{array}$ & 無 & 無 & + & + & - & $H$ & - & - & $H$ & - & + & 150 & III & 膿様 & $H$ & $H$ & + & PAS $160 \mathrm{~g}$ 併用 \\
\hline 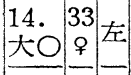 & $\begin{array}{l}15 \mathrm{~g} \\
(20) \\
\end{array}$ & 不良 & 無 & + & + & + & + & - & - & + & - & \pm & 320 & IV & 膿様 & $H$ & H & + & \\
\hline$\left|\begin{array}{ll}15 . & 18 \\
& 0\end{array}\right|$ & \begin{tabular}{|l|}
$6 \mathrm{~g}$ \\
$(24)$ \\
\end{tabular} & 不良 & 正常 & $H$ & 一 & - & \pm & - & 一 & + & - & - & 390 & IV & |膿樣| & $H$ & H & $H$ & PAS $168 \mathrm{~g}$ 併用 \\
\hline
\end{tabular}

室より I NAHについて, 剔除腎の健康組織, 空洞壁, 空洞内容のそれ等の濃度を測定した結果によつても, 空 洞周邊に抗結核劑が充分漻透しないととが分る. Lattimer注動脈撮影により中病巢の腎結核でさえ, 空洞周 邊の血行の不充分になるととを報告して居り ${ }^{37)}$, このと とが空洞治瘾に大きな障害をあたえているのであろう。 以上の事實が腎結核の初期に効果を示す化學療法も, 一 度空洞の形成された症例では効果が不充分になることを 示すものであろう。

b) 剔除腎空洞内容乞腎組織空洞壁

空洞面の清浄化の進んでいる症例には, 空洞内容が乾 酪狀より膿様に, 次いで黄色水様, 水様清澄に變化す る.腎孟と交通のある空洞壁の場合には腎空洞の清浄化 こ腎内容の變化がある程度一致している.唯 I NAH,
I HM S では血性の色調究帯びた例が稍く多い.

c) 組織像と結核菌

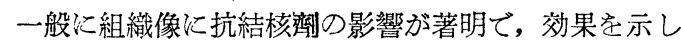
た症例も空洞壁に附着する乾酪物質中に結核菌を認め, 且つ大半は結核菌の培養に成功している. 即与組織學的 に結檬性病巢が治癒に近い狀態を示したとしても尚結核 菌の培養に成功する場合は, 再びその部分より再發の起 る可能性を持つている. S M使用例の第14及び15例では 一時結核菌が陰性化したが，SM中止後再び陽性化し， 剔除した症例であり，第16例は腎盂の狭窄のために結核 菌陰性化を示したが，剔除後狭窄部内の乾酪物質中に結 核菌を認め且つ培養陽性であつた。しかしこの 3 例はい づれも組織學的に著明な効果を示している。

Hobby $\left.{ }^{145}\right)$ 等は肺結核の剔除標本中に組織學的には殆 んぞ治瘾を思わせる症例も空洞壁に附着せる乾酪物質よ 
り培坫陽性である例を報告している．腎結核に於いても 同様で，組織學的に治惩に近い場合でも完全に治㽷した とは考えられず, 組織像の効果注治癒と一致しないもの であろう。

d) 尿所見と腎組織像

尿所見怯化學療法により，非常に改善される例も多い が，剔除前の尿中白血球快，腎盂，尿管の狭窄及び閉塞 のない症例では大體架洞内容と平行して居り, 組織に好 影響をあたえた例は，尿所見も改善している．即ち空洞 壁の清浄化，淩出性炎症の停止が，尿所見に好影響をあ たえているのであるう．しかしかっる例のわづかに附着 せる乾酪物質内に，結核菌が生存している場合怯，藥劑 中止により再燃の可能性がある故，尿所見の改善後も長 期の化學療法を施行する必要がある．尿所見の正常化を 認めた例は，その腎孟，尿管に閉塞のないととを確める と共に化學療法を續けるべきである。

e）腎組織像乞耐性

Dick によれば SM，INAH の單獨治潦例で，長期 治療の場合に，腎實質内の結核性病變恃短期治療例より 効果を示すが，空洞壁に再び急性病變を認めて抢り，と れは耐性菌によつて起るという．著者のINAHの症例 3 注空洞壁に周圍えの進行を思わしめる像がある。この 例以顯微鏡的にも結核菌は認められず，培養も不成功で 西つた罵に耐性の测定が出來なかつたので，結論を得る 汇到らなかつた。

\section{(9) 小 括}

155例の腎結核患者に化學療法を施行して，次のとと 安知つた。

（1）各種の抗結核劑の使用により，臨床的に尿所見 の改善及び尿中結核菌の消失が起る.

尿所見の改善に要した日數を比較すると， SM=併用 (1) $\geqq$ I NAH $=$ I HM S > 併用 (2) > T B I = P54の 順であつた． S M, 併用 (1)，INAH及び I HM S は 著效を呈するけれぞも，SM毎日 $1 \mathrm{~g}$ の連續使用以副作 用を起しやすい及 I NAH，I HM S 以單獨使用で 1 度 改善した尿所見が惡化するとともあるので，併用療法が 必要である。

（2）尿所見の改善と結核菌尿の消失が起つた例を剔 除して檢索すると，我々が豫期していたより効果が不充 分であり空洞内より結核菌培養に成功する場合が多く， .特に大空洞を形成している例注効果も少い。

（3）腎組織に及汸す影響としては，いづれの抗結核 劑を使用しても，腎空洞內の清浄化，上皮再生，類上皮
細胞層萎縮が起る．又腎賽質内の結核結節では，類上皮 細胞の萎縮空洞化，巨細胞の菱縮變形等が起り，結核結

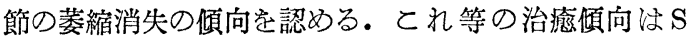
M, INAH，I HMSで比較的早く起り，TBIでは 効果が不充分であるしかしいづれの藥劑も腎機能の良 い症例では上述の影響が早く起り且つ著明であり，同程 度の病戀では長期使用例添で効果があきらかである。

（4）腎㙉と交通のある空洞安持つ症例では，腎空洞 壁の清浄化と出资の消退に伴つて, 空洞内容が清浄化 され，又空洞内容の變化に伴つて尿所見の改善が起るも のと考えられる。

（5） S M28 g 使用のII 群に屬する症例は, 組織學的 に非常な効果を示し，腎剔除前の尿所見も完全に正常で あつたけれども, 空洞内に僅かに附着していた乾酪物質 より結核菌の培羑に成功した。 即ち尿所見が正常化し て，組織學的に殆んぞ治癒を思わせる症例も，實際には 治瘉していない場合むある。

\section{第 II 節 膀胱結核}

膀胱結核 156 例に化學療法を施行した. その種類と例 數它表示する (第 6 表).

てれ等の症例について, 膀胱容量, 膀胱症狀, 膀胱粘 膜の戀化等について觀察した。

用量については腎結核と同様である。

(1) 膀胱容量

殆んぞ全症例に増加を認めたが，一部膀胱粘膜が正常 に成りながら減少を示した例もある (第 7 表).

但し胱膀粘膜の結核性變化が強度である症例と, 萎縮 膀胱を思わしめる症例では容量の急激の減少を認めるこ こもあつた。

容量の増加した日數は S M 20 g（20日）前後, T B I $3 \mathrm{~g}$ (40日) 以上, P54 3g (約40日), I NAH $3 \mathrm{~g}$ (約 20 日), I H M S 20 g（約 20 日）であり併用 (1)は 20 日，併用（2）は30日位である。

即ち膀胱容量増加についての効果を比較すると.

$\mathrm{S} \mathrm{M}=$ 併用 (1) $=\mathrm{I} \mathrm{NAH}=\mathrm{IHMS}>$ 併用 (2) $>\mathrm{T}$ B I = P54と成る.

(2) 自覺症狀

膀胱結核が存在しても膀胱容量の $200 \mathrm{cc}$ 以上ある例で 以自覺症狀学缺く場合もかなり多い。自覺症狀のうち, 頻尿之排尿痛を訴えた例について，治療により症狀の消 失した日數を比較した（第 8 表）。

膀胱結核の病變により, ある程度の差认むるが, 頻尿 の消失した平均日數在比校して見ると， S M，INA 
第 6 表 膀胱結核に對する化學療法

\begin{tabular}{|c|c|c|c|c|c|c|c|c|}
\hline 種 類 & SM & TBI & PAS & P54 & INAH & IHMS & 併用 (1) & 併用(2) \\
\hline 症 例 & 31 & 31 & 3 & 8 & 38 & 18 & 8 & 19 \\
\hline
\end{tabular}

第 7 表 膀胼容量に及ぼす影響

\begin{tabular}{|c|c|c|c|c|c|c|c|c|c|c|c|c|c|}
\hline 種 & 類 & & SM & & \multicolumn{4}{|c|}{ TBI(P54) } & \multicolumn{5}{|c|}{ INAH } \\
\hline \multicolumn{2}{|c|}{ 使用量或は日數 } & \multicolumn{3}{|c|}{$10 \sim 19|20 \sim 39| 40 \sim 60 \mid$} & $0 \sim 3 \mathrm{~g}$ & $3 \sim 6 \mathrm{~g}$ & \multirow{2}{*}{$\begin{array}{r}6 \sim 10 \\
\mathrm{~g}\end{array}$} & $\begin{array}{l}10 \mathrm{~g} \\
\text { 以上 }\end{array}$ & \multicolumn{2}{|c|}{$0 \sim 3 \mathrm{~g} \mid 3 \sim 6 \mathrm{~g}$} & \multicolumn{2}{|c|}{$6 \sim 1010 \sim 20$} & $\begin{array}{l}20 \mathrm{~g} \\
\text { 以上 }\end{array}$ \\
\hline 正 & 常 & 2 & 0 & 0 & 0 & 0 & & & 1 & 2 & 0 & 2 & 1 \\
\hline 減 & 少 & 1 & 1 & 0 & $0(1)$ & 0 & 1 & 0 & 0 & 0 & 0 & 1 & 0 \\
\hline 不 & $\begin{array}{l}\text { 變 } \\
\end{array}$ & 2 & 0 & 0 & $3(1)$ & 0 & $0(1)$ & 2 & 3 & 1 & 0 & 1 & 0 \\
\hline \multirow{3}{*}{ 賭加 } & $0 \sim 50 \mathrm{cc}$ & 3 & 3 & 0 & $1(1)$ & $3(2)$ & 2 & $6(1)$ & 1 & 3 & 1 & 2 & 1 \\
\hline & $\sim 100 \mathrm{cc}$ & 3 & 4 & 4 & 0 & 1 & 1 & $4(1)$ & 1 & 0 & 1 & 2 & 1 \\
\hline & $\overline{100 \mathrm{cc} \sim}$ & 0 & 3 & 4 & 0 & 0 & 2 & 4 & 2 & 2 & 0 & 0 & 0 \\
\hline
\end{tabular}

\begin{tabular}{|c|c|c|c|c|c|c|c|c|c|c|}
\hline \multicolumn{4}{|c|}{ IHMS } & \multicolumn{3}{|c|}{ 併 用 (1) } & \multicolumn{4}{|c|}{ 併 用 (2) } \\
\hline $0 \sim 40 \mathrm{~g}$ & $40 \sim 60 \mathrm{~g}$ & $\begin{array}{r}60 \sim 100 \\
\mathrm{~g}\end{array}$ & $\begin{array}{l}100 \mathrm{~g} \\
\text { 以上 }\end{array}$ & $10 \sim-19$ 日 & 20～39日 & 40日以上 & $10 \sim 30$ 日 & $30 \sim 60$ 日 & $60 \sim 90$ 日 & $\begin{array}{r}60 \sim 120 \\
\text { 日 }\end{array}$ \\
\hline 0 & 2 & 1 & 0 & 0 & 1 & 1 & 1 & 1 & 0 & 1 \\
\hline 1 & 1 & 0 & 0 & 0 & 0 & 0 & 0 & 0 & 0 & 0 \\
\hline 1 & 0 & 0 & 0 & 1 & 0 & 0 & 0 & 0 & 0 & 0 \\
\hline 3 & 1 & 1 & 1 & 2 & 1 & 0 & 1 & 2 & 1 & 2 \\
\hline 1 & 3 & 0 & 1 & 0 & 1 & 0 & 0 & 2 & 1 & 1 \\
\hline 1 & 0 & 0 & 0 & 0 & 0 & 1 & 0 & 1 & 0 & 3 \\
\hline
\end{tabular}

第 8 表 自覺症狀消失迄の日數

\begin{tabular}{|c|c|c|c|c|c|c|c|c|c|c|c|}
\hline \multirow{3}{*}{ 種 } & \multirow{3}{*}{ 症例 } & \multicolumn{5}{|c|}{ 頻 } & \multicolumn{3}{|c|}{ 排 } & \multicolumn{2}{|l|}{ 尿痛 } \\
\hline & & \multirow{2}{*}{ 無 } & \multirow{2}{*}{ 有 } & \multirow{2}{*}{ 不變 } & \multicolumn{2}{|c|}{ 消失迄の日數 } & \multirow{2}{*}{ 無 } & \multirow{2}{*}{ 有 } & \multirow{2}{*}{ 不變 } & \multicolumn{2}{|c|}{ 消失迄の日數 } \\
\hline & & & & & 最短一最長 & 平均 & & & & 最短一最長 & 本均 \\
\hline SM & 31 & 11 & 20 & 3 & $7 \sim 46$ & 17 & 7 & 24 & 1 & $3 \sim 36$ & 12 \\
\hline TBI & 31 & 9 & 22 & 4 & $15 \sim 150$ & 66 & 8 & 23 & 1 & $6 \sim 120$ & 56 \\
\hline INAH & 38 & 16 & 22 & 2 & $4 \sim 55$ & 18 & 18 & 20 & 1 & $2-53$ & 15 \\
\hline IHMS & 18 & 11 & 7 & 1 & $9 \sim 30$ & 19 & 10 & 8 & 1 & $1 \sim 30$ & 14 \\
\hline PAS & 3 & 2 & 1 & 0 & 26 & - & 0 & 3 & 0 & $6 \sim 60$ & 41 \\
\hline$P \sim 54$ & 8 & 4 & 4 & 2 & $42 \sim 48$ & 46 & 4 & 4 & 1 & $22 \sim 40$ & 30 \\
\hline 併用(1) & 8 & 3 & 6 & 2 & $4 \sim 34$ & 17 & 4 & 5 & 1 & $4 \sim 27$ & 13 \\
\hline 併用 (2) & 19 & 5 & 14 & 1 & $6 \sim 72$ & 29 & 5 & 14 & 0 & $3 \sim 62$ & 21 \\
\hline
\end{tabular}

H，I HMS 及び併用（1）は20日以内で殆んざその間に 優劣なく, 次いで併用 (2)の約 30 日, P54の64日, T B I の 66 日である. 排尿痛の消失も S M, 併用 (1), I NAH及び I HM S は殆んぞ優劣の差はなく，やや併 用 (2)が退く, P54, PAS, T B Iの順に成る, 以上 のことょり, SM, 併用 (1), INAH, I HMS S殆 んぞ同效果であり，併用（2）は約 1.5〜 2 倍, PASは
$2 \sim 3$ 倍, P 54 は約 3 倍, T B I は約 4 倍の治療日數学 要することを知つた。

(3) 膀胱粘膜

膀胱鏡的に膀胱粘膜の變化を觀察した (第 9 表). 此の 場合病戀が輕度のものは化學療法もよく奏効し, 最も早 く治瘾した例柱 S M, I HM S の10日, I NAHの15日 であり，T B I，P54は治癒するのに長い日數を要して 
第 9 表 膀脱粘膜の變化

\begin{tabular}{|c|c|c|c|c|c|c|c|c|c|c|c|c|c|}
\hline 種 & 類 & \multicolumn{3}{|c|}{ SM } & \multicolumn{4}{|c|}{ TBI(P54) } & \multicolumn{5}{|c|}{ INAH } \\
\hline 粘膜變化 & 使用量又は日數 & $\begin{array}{r}1 \sim 19 \\
\mathrm{~g} \\
\end{array}$ & $\begin{array}{r}20 \sim 39 \\
\mathrm{~g}\end{array}$ & $\begin{array}{l}40 \mathrm{~g} \\
\text { 以上 }\end{array}$ & $0 \sim 3 \mathrm{~g}$ & $3 \sim 6 \mathrm{~g}$ & $\begin{array}{r}6 \sim 10 \\
\mathrm{~g}\end{array}$ & $\begin{array}{l}10 \mathrm{~g} \\
\text { 以上 }\end{array}$ & $0 \sim 3 g$ & $3 \sim 6 \mathrm{~g}$ & $\begin{array}{r}6 \sim 10 \\
\mathrm{~g}\end{array}$ & $\begin{array}{r}-20 \\
\mathrm{~g}\end{array}$ & $\begin{array}{l}20 \mathrm{~g} \\
\text { 以上 }\end{array}$ \\
\hline 全 & 治 & 2 & 2 & 3 & $5(1)$ & $1(2)$ & 3 & 4 & 3 & 5 & 2 & 5 & 3 \\
\hline 瘦 & 痕 & 1 & 2 & 2 & 0 & $2(1)$ & 0 & 4 & 2 & 1 & 0 & 2 & 0 \\
\hline 輕 & 快 & 6 & 5 & 3 & $4(1)$ & 3 & 1 & $1(1)$ & 2 & 1 & 1 & 1 & 0 \\
\hline 末 & 治 & 2 & 2 & 0 & $0(1)$ & 0 & 1 & 1 & 1 & 1 & 1 & 0 & 0 \\
\hline
\end{tabular}

\begin{tabular}{|c|c|c|c|c|c|c|c|c|c|c|}
\hline \multicolumn{4}{|c|}{ IHMS } & \multicolumn{3}{|c|}{ 併 用 $(1)$} & \multicolumn{4}{|c|}{ 併 用 (2) } \\
\hline $0 \sim 20 \mathrm{~g}$ & $20 \sim 40 \mathrm{~g}$ & $40 \sim 60 \mathrm{~g}$ & $60 \mathrm{~g}$ 以上 & 1〜19日 & 20～39日 & 40 日以上 & $1 \sim 30$ 日 & $30 \sim 60$ 日 & $60 \sim 90$ 日 & $90 \sim 120 日$ \\
\hline 4 & 1 & 2 & 1 & 0 & 1 & 2 & 2 & 2 & 2 & 3 \\
\hline 1 & 0 & 2 & 1 & 1 & 0 & 0 & 1 & 0 & 1 & 1 \\
\hline 1 & 1 & 0 & 0 & 1 & 2 & 0 & 1 & 1 & 0 & 1 \\
\hline 1 & 1 & 0 & 0 & 1 & 0 & 0 & 0 & 0 & 1 & 0 \\
\hline
\end{tabular}

第10表 膀胱粘膜治療に要した日數(膀胱容量200cc以上)

\begin{tabular}{|c|c|c|c|c|c|c|c|c|}
\hline 種 類 & SM & TBI & INAH & IHMS & P54 & PAS & 併用 (1) & 併用(2) \\
\hline 症 例 數 & 6 & 8 & 9 & 5 & 3 & 2 & 2 & 3 \\
\hline 最短 (日) & 10 & 47 & 8 & 8 & 28 & 43 & 16 & 20 \\
\hline 最長 $($ 日) & 26 & 89 & 30 & 27 & 85 & 68 & 20 & 41 \\
\hline 平均 (日) & 18.5 & 61.5 & 18.5 & 17.6 & 62 & 52 & 18 & 32 \\
\hline
\end{tabular}

いる.しかし一般に粘膜上に白苔学有した症例柱治瘾し がたかつた。

㗄胱容量が $200 \mathrm{cc}$ 以上の症例て, 瘢痕治癒を加えて治 癒した日數を觀察した (第10表).

その平均日數で比較して見ても分る椂に， S M, I N $\mathrm{AH}$ ，IHMS，併用（1）は殆んど同効果で，併用 (2) がや>劣り，PAS, T B I, P54の順に成る。

尚これ等の症例中には尿中結核菌が陽性でありながら 膀胱結核の治癒した例も少くなかつたし，再發を見た症 例むむる。

膀胱の高度の潰瘍では, 長期の化學療法でも治瘾し難 い例があることは事實である。

(4) 小 括

156例の膀胱結核に化學療法学施行した結果, 次の事 賔学認めた。

(1) SM, T B I, I NA S, I HM S, PA S 及 び併用 (1), 併用 (2)はいづれも膀胱結核に効果がある.

（2）膀胱容量の増加，自覺症狀の消失，膀胱粘膜の 變化に對する治療日數の比較により，SM，併用 (1)， I NAS, I HMS は殆んど優劣の差を認めず, 前 2 者 が稍とすぐれているかと思われる程度であつた。 以上の
化學療法に比して併用（2）は効果が扝とり約 1.5倍つ治 療日數要要し, PAS 没的 $2 \sim 3$ 倍, T B I, P 54 注約 $3 \sim 4$ 倍の日數を要した。

（3）長期の化學療法でも治癒しがたい例もある.

\section{第節 生殖器結核}

1）副暲丸結核

42例の副殬丸結核に S M, T B I, I NAH, I HM Sを施行した。

\section{a) SM療法}

$\mathrm{S}$ M單獨による治療は 5 例 $10 \mathrm{~g}$ ～30 g 使用例であり， その臨床所見に於いて急性症状の消退を思わしめる程度 の効果を示したものは 2 例であり，20〜40g使用した例 む効果は不確實であつた. このうち 3 例に組織學的检查 を施行したが，1例に䢧出性炎症の消退と 2 例に類上皮 細胞の萎縮を認めた. しかしその内の 2 例は膿痬中より 結核菌の培養に成功して居り, 治瘾の望みは少いものと 思われた。即ち一度形成された乾酪物質はその中に結稯 菌字有し, その結核菌はSMで死隇せぎ，又その乾酪物 質の排出が困難なためであろう。
b) T B I治療 
T B I の症例は17例 0.6 21.6 g使用例であり，乙の 了与 3 例快臨床的治癒を思わしめたが, いづれも極めて 初期と思われる例であつた. 4 例は浸潤の縮小を見たが 他の 2 例怡治療中に惡化している. 3 例の治瘾を思うし めた例怡約 1 ケ月間總量 $2 \mathrm{~g}$ の治療例であり, Boshamerのい弓乾酪化の起らなかつた症例であろう。このよ うな例は他のいづれの化學療法でも有效であつたのかも 知れない. 3 例の剔出後の組織學的檢查によると, 乾酪 巢中に結核菌が存在し, SMV比して組織學的の効果も 不充分であり，炎症の停止を認めない症例もある.

c) INAH治療

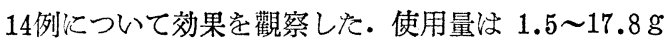
であり，いづれの例も臨床的に治癒を思わしめる程効果 のあつた例梳ない.とのうち 2 例に組織學的检索を施行 した. 1 例梳 $3.5 \mathrm{~g}$ 使用により, 漻出性炎症の停止, 類 上皮細胞の萎縮学認めたが, 他の $9.8 \mathrm{~g}$ 使用例恰出性 炎症も停止せず，類上皮細胞の萎縮も認め得なかつた。 從つて一部組織に影響をあたえるとしても，乾酪巢の存 在决認められ治癒性困難と考えられる。

\section{d) I HM S 治療}

6 例つ I HM S 單獨治療, 約 $15 \sim 35 \mathrm{~g}$ の使用例では, 臨床的儿治療と思わしめる症例はなく, 指頭大の浸潤は 消失していない。

以上のべたように種々の化學療法も副䆭丸結核に效果 寺すにには極めて初期の症例のみであり，一度乾酪巣 学形成せる例は, 効果が不充分て治瘾せしめ得ない. 從 つて現在の最良の方法は手術前後に化學療法安施行する ことで, それは瘦孔の發生と他側及び他臓器えの結核の 侵裂を防止するに止宋る。

2）前立腺結核及び精囊腺結核

前立腺結核に對してS M11例, T B I 8 例, I NAH 16例, I HMS 6 例の効果を觀祭した. これ等の抗結核 劑俧いづれも充分たる効果を認めがたく, 多少症狀に變 化を來した程度である。

精囊腺結核に對しても全く同様で確實な効果を認めた 例注ない. これ等の生殖器結核は一般に強い乾酪化を起 傾向がある. しかし化學療法によつても乾酪の排泄が 不充分なために靑効し難いのであろう. 又これ等の藥劑 がこの乾酪物質内に排泄されたとしても, 結核菌安死減 せし必得る程ではないので, 組織内の炎症の停止も完全 に起らぬすのと考えられる。

3) 小括

(1) 副踤丸結核は一度乾酪巢を形成した場合には化 學療法にて治瘾也しめるととは困難であり, 手術的に剔
出しその前後に化學療法を行引べきである。

（2）前立腺及び精露腺結核に對しても化學療法注効 果が不充分である。

\section{B・吸收及び排泄}

\section{(1) $\mathrm{SM}$}

川上氏の培地により重層法で測定した。

1）血中浱度

$0.5 \mathrm{~g}$ 每12時間及び $1 \mathrm{~g} 1$ 包笳肉内注射による血中濃 度安測定した（第11，12表）。

第11表 $\mathrm{SM} 0.5 \mathrm{~g}$ 每12時間血中濃度(24例)

\begin{tabular}{|c|c|c|c|c|c|c|}
\hline 時間 & 1 & 3 & 5 & 6 & 7 & 12 \\
\hline 最高值 $(\gamma)$ & 36.4 & 19.4 & 13.3 & 9.3 & 7.2 & 4.0 \\
\hline 最 低 & 13.7 & 8.9 & 7.5 & 2.1 & 1.6 & 0.2 \\
\hline 均 & 26.1 & 14.7 & 9.6 & 6.6 & 4.7 & 1.6 \\
\hline
\end{tabular}

第12表 SM 1 g 1 回筋注血中濃度 ( 5 例)

\begin{tabular}{|c|c|c|c|c|c|c|}
\hline 時間 & 1 & 3 & 6 & 9 & 12 & 24 \\
\hline 最高值 $(\gamma)$ & 112 & 132 & 61 & 37 & 21.0 & 4.4 \\
\hline 最 低 值 & 68 & 56 & 22 & 20.2 & 7.0 & spur \\
\hline 均 & 91.8 & 85.2 & 39.2 & 24.9 & 11.2 & 2.2 \\
\hline
\end{tabular}

$0.5 \mathrm{~g}$ では注射後 1 時間平均 $26.1 \mathrm{r} / \mathrm{cc}, 1 \mathrm{~g}$ では平均 $91.8 r$ lcc に昇り, 除こに下降して前者では12時間, 後 者では24時間 S Mが血中内に存在する.

口）尿中濃度

$0.5 \mathrm{~g}$ 毎12時間筋注で 4 例 5 回の測定は第 13 表に表示 する. 刃1 g 1 间筋注も第14表に表示する. この場合尿 中 $1 \mathrm{cck}$ 含有される S M濃度は尿量に上り左右され，同 1 人 2 回の測定でも可成り動摆を示している.

八）剔除㻉組織, 空洞壁及び空洞内容 S M 濃度

これについては著者は既に發表しているので略記す る.

健康部と思われる腎組織は空洞壁より SM 濃度が高 く, 空洞内は一般に更に低濃度と成つている。從つて Mが空洞壁には充分澄透しないと考えられる。

(2) PAS

PASの測定について津田試薬, 過クロール鐵による 定量法を追試したが不充分なる結果を得たので，Alin等 の方法を用いて測定した.

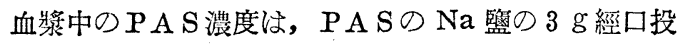
與 3 例の測定の結果, 投與後 30 分にして11.0 13.0mg/dl, 1 時間半で12.5〜 14.5mg/dl, 3 時間 5.0〜 7.5mg/dlなる 
第13表 SM $0.5 \mathrm{~g}$ 每12時間筋洼による尿中濃度及び排泄量

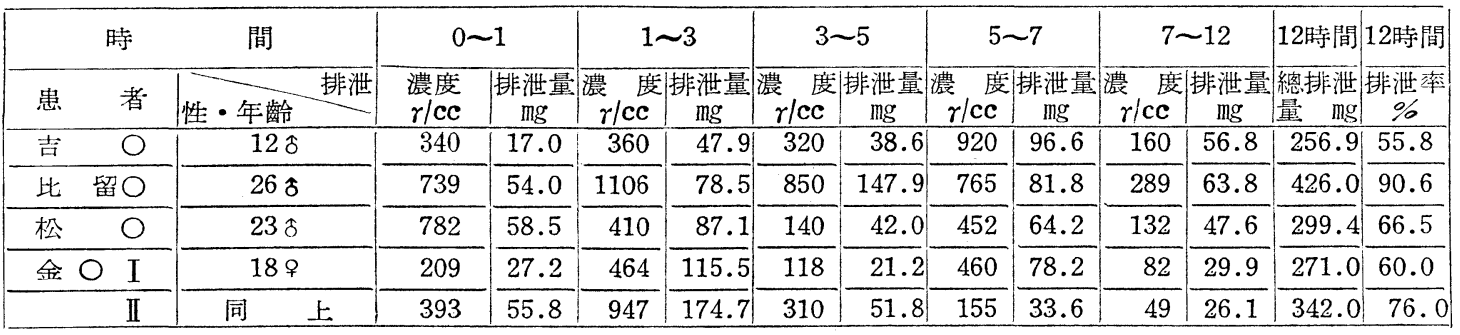

第14表 SM $1 \mathrm{~g}$ 使用による尿中濃度及び排泄量

\begin{tabular}{|c|c|c|c|c|c|c|c|c|c|c|c|c|c|c|}
\hline \multicolumn{2}{|c|}{ 時 } & 間 & \multicolumn{2}{|c|}{$0 \sim 1$} & \multicolumn{2}{|c|}{$1 \sim 3$} & \multicolumn{2}{|c|}{$3 \sim 5$} & \multicolumn{2}{|c|}{$5 \sim 7$} & \multicolumn{2}{|c|}{$7 \sim 12$} & |12時間| & 12時間 \\
\hline 患 & 者 & 性・年齢 & $\begin{array}{l}\text { 濃 } \text { 度 } \\
r / c c\end{array}$ & \begin{tabular}{|c|} 
排泄量 \\
mg
\end{tabular} & $\begin{array}{l}\text { 濃 } \\
\text { r!ce } \\
\end{array}$ & 排泄量 & 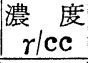 & $\left|\begin{array}{c}\text { 排泄量 } \\
\mathrm{mg}\end{array}\right|$ & $\begin{array}{l}\text { 濃 } \\
r^{\prime}\end{array}$ & 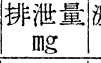 & $\begin{array}{l}\text { 濃 } \\
r / c c \\
\end{array}$ & $\mid \begin{array}{c}\mid \begin{array}{c}\mid \\
\text { mg }\end{array} \\
\text { mg 泄量 }\end{array}$ & | & \begin{tabular}{|c|}
$\mid$ 排泄率 \\
$\%$
\end{tabular} \\
\hline 濱 & 0 & \begin{tabular}{|l|}
$28 \%$ \\
\end{tabular} & 1900 & 129.2 & 1250 & 188.8 & 620 & 62.0 & 230 & 149.0 & 8.9 & 1.6 & \begin{tabular}{|l|l|}
596.5 \\
\end{tabular} & 39.65 \\
\hline 田久 & 0 & $27 \hat{\jmath}$ & 1600 & 144 & 1400 & 288 & 912 & 160.4 & 280 & 128.8 & 16 & 128.0 & 848.4 & 84.84 \\
\hline 湯 & 0 & $23 \hat{\delta}$ & 1600 & 146 & 1450 & 214 & 1080 & 270.0 & 390 & 120.0 & 0.9 & 22.1 & $\mid 897.6$ & 89.76 \\
\hline
\end{tabular}

第15表 SM の副作用

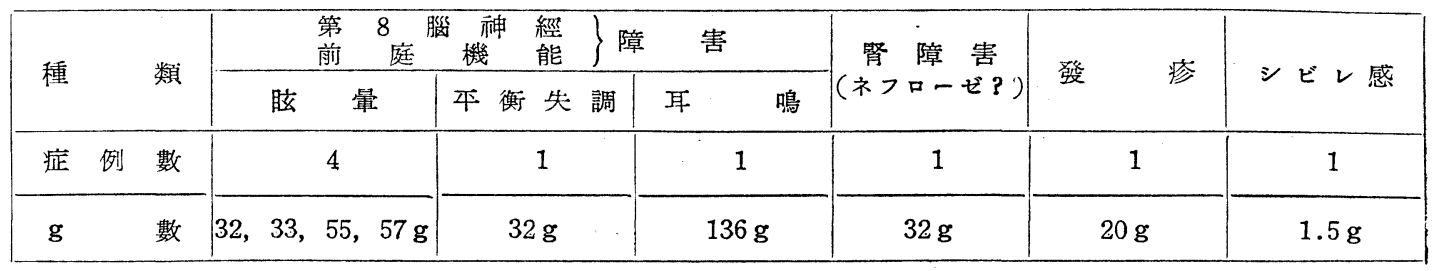

值を得た。

\section{(3) I NAH}

I NAHについて詳細な報告は既に教室より發表して いるので略記する。

1）血中濃度

經口投與 $3 \mathrm{mg} / \mathrm{kg}$ では 6 時間で最高 $3.4 r / \mathrm{cc}$ と成り投 與後 1 時間乃至 12 時間は $1.2 \gamma / \mathrm{cc}$ の血中濃度を持續す る.

口) 尿中濃度

經口投與 $3 \mathrm{mg} / \mathrm{kg} 1$ 包投與で $4 \sim 6$ 時間が最高と成り $191 \gamma /$ ccで 8 時間後より急激化下降して14〜24時間は10 $r / \mathrm{cc}$ と成り, 總排泄量は55.4\%であつた.

八）剔除腎組織及び空洞内濃度

正常腎組織は空洞周邊より高いが，空洞内浭化高く 成つた。これは比較的健康腎杯部よりの尿が空洞内に流 入するためと思われる. 空洞内に密着している乾酪物質 は更に低いものであろう.

(1) $\mathrm{SM}$

\section{イ）尿管及び腎孟狭窄}

S M治療中に患側の尿管狭窄を起す例をしばしば經驗 するが, 一側が健康の場合には特に氣づかない場合も多 く, 尿所見は全く正常に成る. しかし兩側の腎結核, 残 腎結核及び健側の膀脱尿管移項部に狭窄を起すと無尿が 現われる. 2 例の兩側腎結核 20 及び $23 \mathrm{~g}$ 使用例と, 健側 の膀胱尿管移項部に $10 \mathrm{~g}$ にして狭窄を起し無尿に成つた 例を經驗した。尚腎組織を檢査せる $23 \mathrm{~g}$ 使用例で腎孟の 狭窄も認めている。

口）血液像

血液像にエオジノフイリーが來る場合が多く，34例中 14例に認められ，約 $7 \mathrm{~g}$ にして起る場合が多かつた。

八) 副作用

34 例中 6 例に發現した (第15表).とのうち眩暈の 1 例 は $28 \mathrm{~g}$ より出現し, $32 \mathrm{~g}$ にして高度の平衡失調と成り, 1ケ年学經過するも歩行不可能であつた。

(2) T B I

\section{1）尿管狭窄}

著明に狭窄を起した例活認められなかつた。

口) 副作用

全症例69例中内主要な副作用の發現 $\mathrm{g}$ 數と日數を表示 
第16表ＴBI の副作用

\begin{tabular}{|c|c|c|c|c|c|c|c|c|c|c|c|}
\hline & \multicolumn{4}{|c|}{ 發 現 $\mathrm{g}$ 數 } & \multicolumn{2}{|c|}{ 發 } & 現 & \multicolumn{3}{|c|}{ 數 } & \\
\hline 用 & $25 \mathrm{mg}$ & $50 \mathrm{mg}$ & $100 \mathrm{mg}$ & $\begin{array}{c}100 \mathrm{mg} \\
\text { 以上 }\end{array}$ & $\begin{array}{c}\text { 週 } \\
0 \sim 2\end{array}$ & $2 \sim 4$ & $\begin{array}{l}2 \text { 力 } \\
\text { 月迄 }\end{array}$ & $\begin{array}{l}4 \text { 力 } \\
\text { 月迄 }\end{array}$ & $\begin{array}{l}6 \text { 力 } \\
\text { 月迄 }\end{array}$ & $\begin{array}{l}6 \text { 泉 } \\
\text { 以上 }\end{array}$ & \\
\hline 食䓡不振 & 5 & 10 & 7 & 1 & 2 & 6 & 8 & 4 & 2 & 1 & 23 \\
\hline 嘔氣, 嘔吐 & 3 & 2 & 3 & 0 & 1 & 2 & 4 & 1 & 0 & 0 & 8 \\
\hline 腹痛 & 0 & 2 & 2 & 0 & 0 & 0 & 2 & 2 & 0 & 0 & 4 \\
\hline 便䟤, 下脷 & 1 & 1 & 0 & 0 & 0 & 1 & 1 & 0 & 0 & 0 & 2 \\
\hline 眩量, 耳鳴 & 1 & 1 & 2 & 0 & 0 & 0 & 3 & 1 & 0 & 0 & 4 \\
\hline 腦 症 狀 & 0 & 0 & 0 & 0 & 0 & 0 & 0 & 0 & 0 & 0 & 0 \\
\hline 貧 血 & 0 & 2 & 2 & 0 & 0 & 0 & 2 & 2 & 0 & 0 & 4 \\
\hline アグラヌロチトーゼ & 0 & 0 & 0 & 0 & 0 & 0 & 0 & 0 & 0 & 0 & 0 \\
\hline 白血球減少5000以下 & 5 & 3 & 3 & 0 & 2 & 4 & 5 & 0 & 0 & 0 & 11 \\
\hline エオジノフイリー & 4 & 3 & 3 & 0 & 2 & 4 & 2 & 1 & 1 & 0 & 10 \\
\hline 凝血出血時間延長 & 0 & 0 & 0 & 0 & 0 & 0 & 0 & 0 & 0 & 0 & 0 \\
\hline カドミウム反應陽性 & 3 & 3 & 7 & 0 & 2 & 7 & 1 & 2 & 1 & 0 & 13 \\
\hline ヘパトサルフアレン試驗陽性 & 0 & 0 & 0 & 0 & 0 & 0 & 0 & 0 & 0 & 0 & 0 \\
\hline ウロビリノーグン增加 & 7 & 5 & 5 & 0 & 2 & 5 & 6 & 3 & 1 & 0 & 17 \\
\hline 發疹 & 1 & 1 & 1 & 0 & 0 & 1 & 1 & 1 & 0 & 0 & 3 \\
\hline 結 膜 炎 & 0 & 0 & 0 & 0 & 0 & 0 & 0 & 0 & 0 & 0 & 0 \\
\hline 口渴 & 1 & 1 & 0 & 0 & 1 & 0 & 0 & 1 & 0 & 0 & 2 \\
\hline シビレ感 & 0 & 0 & 1 & 0 & 0 & 0 & 0 & 1 & 0 & 0 & 1 \\
\hline 卵アルブミン感作 & 0 & 0 & 0 . & 0 & 0 & 0 & 0 & 0 & 0 & 0 & 0 \\
\hline
\end{tabular}

する(第16表).特に多いものは胃晹障害, 肝障害及び白 血球の減少であり，注意して投藥を見まむらなければな らない.

(3) $\mathrm{P} 54$

9 例の使用中 1 例に惡心, 嘔吐, 2 例に胃腸障害, 1 例に白血球數の減少を認めたが，T B I ๖り稍こ少いょ うである。

(4) PAS

P A S の副作用中最も多いものは胃腸障害であるが, 顆粒狀, $\mathrm{Na}$ 鹽, $\mathrm{Ca}$ 鹽等の出現により副作用が少く成 つて來た. 併用療法を合めて30例中 7 例治強い胃腸障害 を認めたが, そのうち2 例を除いては P A S の種類を戀 えることにより續け得て。 その他發熱と藥劑による中毒 疹の出現を 2 例に認めた。

(5) I NAH

1) 尿管㹨窄

$13.7 \mathrm{~g}$ 使用後に腎孟尿管移項部の狭窄を起した 1 例が ある。

口) 副作用

38例中副作用のため中止したのは 7 例であり, 頭痛 4 例, 惡心 1 例, ウロビリノーゲン陽性 2 例（このうち 1 例は腎刺战症狀と同時に發現した), 反射兇進と排尿開始
遲延 1 例，白血球減少 1 例である. この白血球減少例は T B I む亦白血球を減少せしめた例である.

(6) I HM S

1) 尿管狭窄

1 例に $91 \mathrm{~g}$ 使用後尿管狭窄を惹起した例がある. 口) 副作用

18例中 I NA Hにより下莉を起した症例に同様に下痢 を起した䳕中止した他，下㢉 2 例，惡心，眩暈を起した 例 1 例, 腹痛 1 例, ウロビリノーゲン陽性 2 例を經驗し たが，藥劑を半量にするか，そのま〉續けて支障をきた さなかつた。

\section{D. 細菌學的研究}

結核症に對して, 化學療法学施行すると耐性菌が出現 することは既に多數に報告されている。

腎結核患者に對して，化學療法を施行した場合も同様 に耐性菌が出現する. S M については既に主としてアメ リカ學派よりの報告に接し, 叉INAHについても同様 に耐性が出現すると報告されているが，詳細な報告は少 W.

著者は腎結核患者より分離した結核菌について, 種ふ 
檢索した結果について述べる。

(1)試驗管内最小阻止濃度

化學療法未施行の腎結核患者より分離せる結核菌につ いて, SM, PAS, T B I, I NAH, I HMS の最 小阻止濃度を測定した。分離に使用せる培地は, 主とし て $3 \% \mathrm{KH}_{2} \mathrm{PO}_{4}$ 培地, 一部岡・片倉培地である. 細菌 阻止力に對する測定培地には $1 \% \mathrm{KH}_{2} \mathrm{PO}_{4}$ 培地及び Kirchner培地を使用して關接法により測定した。 培地の 製法注小川氏の論交 ${ }^{143)}$ により作製し，同氏の方法によ り施行し判定したが，固形培地に於いて注集落數が 100 コロニー以下の場合には集落數を算えた.

イ） SM：SM未施行例18株について測定した.

その最小阻止濃度は $0.5 \gamma$ で12株, $1 \gamma$ で 6 株であ り, いづれも $1 \gamma$ 以下で阻止された。

口） T B I ：T B I未施行14株について測定した。

最小阻止濃度は $1 \gamma て ゙ 4$ 株, $2 \gamma て ゙ 5$ 株であり, 残り の 5 株は $1 \gamma$ で發育し, $10 \gamma て ゙$ 阻止されていた。

八) PAS：18株のPAS未施行例について最小阻止 濃度を測定した。 その阻止力は $0.1 \gamma 4$ 株, $0.5 \gamma 5$ 株 であり，他の 9 株は $1 \gamma$ 以下を施行しなかつたが，全部 $1 \gamma$ と阻止された.

$\Rightarrow$ I NAH : 17株の I NAH，IHMSの未施行例
について最小阻止濃度を測定したが, 0.05 ชで 3 株,

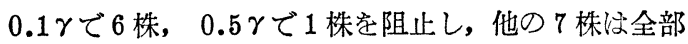
$1 \gamma$ 以下施行しなかつたが, 1 年で阻止されていた。

ホ） I HMS：10株の I NAH, I HMS 未施行例飞 ついて最小阻止瀑度を测定した結果, $0.05 \gamma て ゙ 1$ 株,

$0.1 \gamma て ゙ 8$ 株, $0.5 \gamma$ で 1 株が阻止された.

試驗管内で测定した結核菌の阻止力では I NA H > I HM S > P A S > S M > T B I の順である.

（2）化學療法施行後の結核菌

\section{1) 尿中結核菌}

化學療法施行により，尿中結核菌が顯微鏡的に陰性化 するととは, 既にのべた. しかし化學療法の初期㬎微 鏡的には陰性であつても，培養陽性の例が多い。長期の 化學療法を施行している症例では，逆に鏡检陽性であつ ても，並通の培養方法て陰性例学認める. この點につい

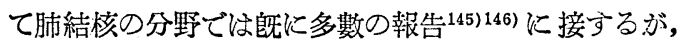
これと同様な症例安筒結核患者にも認められる。これを 知つた當初は培養法の未熟によるものと思つた. しかし その後腎空洞内の結核菌の顯微鏡檢查, 培羑檢査により 鏡檢陽性で培養㓌性例を認めた。

尿中結核菌怯長期の化學療法により，顯微鏡的汇陰性 化を示卞場合が多いので症例注比警的少い（第17表）.

第17表 尿中結核菌鏡檢陽性培養陰性例

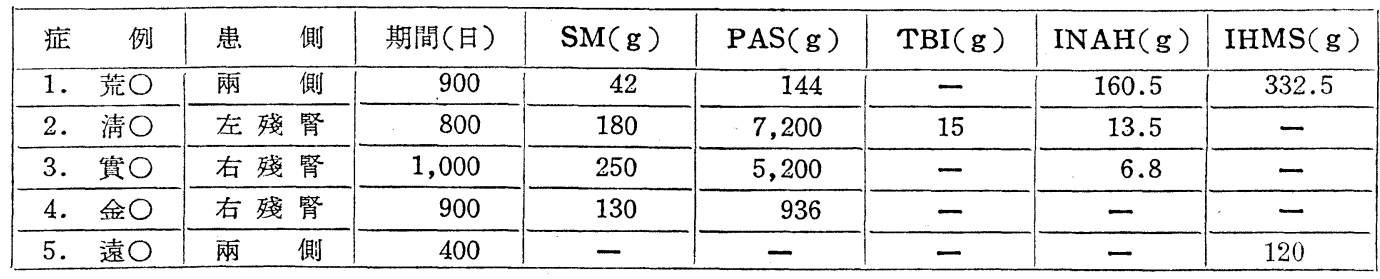

注目すべきことはこれ等の症例が, いづれも兩倒及び 残腎結核である。兩側及び残腎絬核の場合に心，抗結核 劑が患腎より高濃度に排泄される，從つて結核菌が高濃 度の藥劑に接觸している時間が長いために, 死減する か, 弱くなつており, 普通の培養方法では發有困難とな つているのであろう。

\section{口）剔除腎空洞内絬核菌}

化學療法施行後に剔除せる腎空洞内容を檢索すると， 結核菌が鏡檢陽性がありながら，培養陰性例を經驗す る.このような化學療法後の别除標本内に鏡檢陽性, 培 養除性の結核菌があることについては種々の報告に接す るが、いろ゙れも肺結核である. 又とれ等も Hobby 等 ${ }^{145)}$ の報告のように特種な培養方法によれば, 生育する可能
性がある。

Sivertson 等の報告 ${ }^{148)}$ 亿ょれば，腎結核患者の長期 化學療法後の剔除腎空洞内に鏡检でほ結核菌陽性で，培 養及び動物接種試驗陰性例が存在するこいう．著者は動 物試騟を施行しなかつたが，36例中の12例に培羑不成功 例を認めた (第18表).とのうち2 例は空洞内に結核菌安 認め得ず，培養も陰性であつた。

第18表 空洞內結核菌培養成績

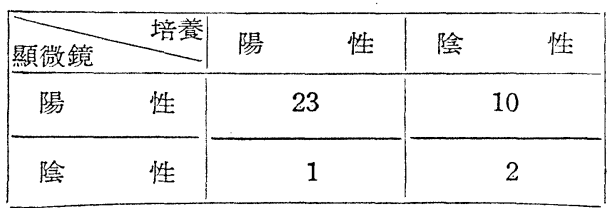


第19表 a. 培養陰性例

\begin{tabular}{|c|c|c|c|c|c|c|c|c|c|c|c|c|c|c|}
\hline \multirow{2}{*}{ 症 } & \multirow{2}{*}{ 例 } & \multicolumn{2}{|c|}{ 空洞內結核菌 } & \multirow{2}{*}{$\begin{array}{l}\text { 使用 } \\
\text { 境養 } \\
\text { 數 }\end{array}$} & \multirow{2}{*}{$\begin{array}{l}\text { I.P. } \\
20 \text { 分 } \\
\text { 排泄 }\end{array}$} & \multirow{2}{*}{$\begin{array}{r}\text { 術尿白 } \\
\text { 所血 } \\
\text { 前見球 }\end{array}$} & \multicolumn{2}{|c|}{ 化 } & 學 & 潦 & \multicolumn{2}{|c|}{ 法 } & \multirow[b]{2}{*}{ 筒病變 } & \multirow{2}{*}{ 備 考 } \\
\hline & & 顯 & 培養 & & & & $\begin{array}{r}\text { 日 } \\
\text { 期間 }\end{array}$ & $S M^{g}$ & PAS & $\begin{array}{r}\mathrm{g} \\
\mathrm{TBI}\end{array}$ & INAH & $\begin{array}{r}\mathrm{g} \\
\mathrm{HMS}\end{array}$ & & \\
\hline 1. 田 & 0 & - & - & 4 & $\mathrm{HH}$ & $H$ & 40 & 0 & 0 & 0 & 12 & 0 & II & \multirow{4}{*}{ 小空洞 } \\
\hline 2. 和 & 0 & - & - & 3 & $H$ & \pm & 80 & 18 & 600 & 2.1 & 0 & 0 & II & \\
\hline 3. 高 & 0 & $\mathrm{HH}$ & - & 8 & HH & - & 120 & 30 & 1,200 & 0 & 0 & 0 & II & \\
\hline 4. 大 & 0 & $t$ & - & 4 & + & 一 & 320 & 30 & 3,200 & 0 & 0 & 0 & II & \\
\hline 5. 荒 & 0 & + & - & 4 & $H$ & + & 90 & 30 & 900 & 0 & 0 & 0 & III & \\
\hline 6. 木 & 0 & $t$ & - & 3 & $H$ & $\mathrm{H}$ & 30 & 0 & 0 & 0 & 7.1 & 0 & IV & \\
\hline 7. 石 & $\mathrm{O}$ & $\mathrm{HH}$ & - & 5 & $H$ & \pm & 21 & 0 & 0 & 0 & 6.3 & 0 & IV & \\
\hline 8. 藤 & 0 & + & - & 3 & - & + & 180 & 65 & 1,800 & 0 & 0 & 0 & IV & \\
\hline 9. 石 & 0 & $H$ & - & 4 & - & - & 50 & 0 & 0 & 0 & 15 & 0 & IV & \\
\hline 10. 須 & 0 & + & - & 4 & $H$ & - & 51 & 3 & 60 & 0 & 0 & 51 & IV & \\
\hline 11. 西 & 0 & + & - & 3 & - & $H$ & 18 & 12 & 180 & 0 & 1.8 & 0 & IV & \\
\hline 12. 湯 & 0 & + & - & 3 & - & $\mathrm{HH}$ & 32 & 30 & 320 & 0 & 0 & 0 & IV & \\
\hline
\end{tabular}

第19表 b. 長期培養により結核菌陽性例

\begin{tabular}{|c|c|c|c|c|c|c|c|c|c|c|c|c|c|}
\hline \multirow{2}{*}{ 例 } & \multicolumn{2}{|c|}{ 空洞內結核菌 } & \multirow{2}{*}{$\begin{array}{l}\text { 使用 } \\
\text { 培養 } \\
\text { 數 }\end{array}$} & \multirow{2}{*}{$\begin{array}{l}\text { I.P. } \\
20 \text { 分 } \\
\text { 排泄 }\end{array}$} & \multirow{2}{*}{ 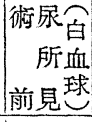 } & \multicolumn{2}{|r|}{ 化 } & 學 & 療 & \multicolumn{2}{|c|}{ 法 } & \multirow[b]{2}{*}{ 腎病變 } & \multirow{2}{*}{ 備 } \\
\hline & 顯 & 培養 & & & & $\begin{array}{r}\text { 日 } \\
\text { 期間 }\end{array}$ & $\mathrm{SM}^{\mathrm{g}}$ & PAS & TBI & INA & $\begin{array}{r}\mathbf{g} \\
\mathrm{IHMS}\end{array}$ & & \\
\hline 1. 川 & H & + & $2 / 8$ & $H$ & H & 180 & 0 & 1,328 & 0 & 0 & 95 & III & 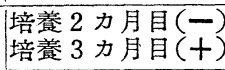 \\
\hline 2 . 福 $\bigcirc$ & $H$ & + & $2 ! 6$ & - & $H$ & 360 & 148 & 120 & 0 & 0 & 0 & IV & 上 \\
\hline
\end{tabular}

培養不成功例について化學療法の期間, 使用量, 病 變, 腎機能, 剔除前の膀胱尿中の白血球を表示する（第 19表a).

尚てれ等の陰性例に，檢查材料内に含有されている抗 結核劑によつて發育阻止の起る場合も存在することは當 然豫想されるととであり, Donovick 等149 は SMについ て, 高橋 ${ }^{150}$ は I NAHとPA S てついでその不活性化比 よる培養を行つている。これ等安利用すれれ゙更に陽性率 を高め得るであろろ.

（3）剔除繁病變と培着成績

12例の培善不成功例について, その病變を見ると, Sivertson 等のWろ小空洞に對する長期化學療法例と思わ れる例は第 2 〜 例迄である.第 1 例は小空洞であり腎 機能が非常によい. 第 6,7 例は腎機能が比較的良好に 保持されていた例である. 第 8 例は約半年の化學療法 例，第 $9 ， 10$ 例々閉塞性に變つた例である.

（4）剔除腎空洞内結核菌の培養期間

長期化學療法後の 2 例に於いて, 2 ケ月の觀察で培盖 陰性であつたが，3 ケ月後に 2 例共數コロニーの結核菌 の發育定認め, 其の後コロニー數の増加した例がある (第19表b).

他の症例では約 2 ケ月で觀察を中止した例が大部分で あるので, 或は更に長期間の培養で陽性化する可能性が あつたのであろろ、とれは既にのべた Hobby 等も指摘 し，小川も報告している146)・しかし腎結核については未 だとのような報告には接していない.

（5）抗結核劑に對する而性

1) 尿中結核菌

化學療法施行中の患者の尿中結核菌を分離することは 困難な場合が多く, 特に長期化學䇣法を繼續する場合に 多くの症例では尿中結核菌が陰性に成るので症例は12例 にすぎい(第20表).

このうち第 1 〜 例は片側腎結核, 第 4〜 7 例《兩側 腎結核，第 8１2例は残腎結核症例でむる。

第 1 例は患側の I.P.の排泄良好な例であり，手衡療 法学欲せず，化學療法のみにより治療した。使用せる藥 劑はSM, PAS, T B I, I NAHの各單獨使用例で ある.SMは20g使用で $1 r / c c$ 迄陽性, T B I は約 1 年 間使用で 100 耐性であるが，PAS，INAHは耐性 でない. 


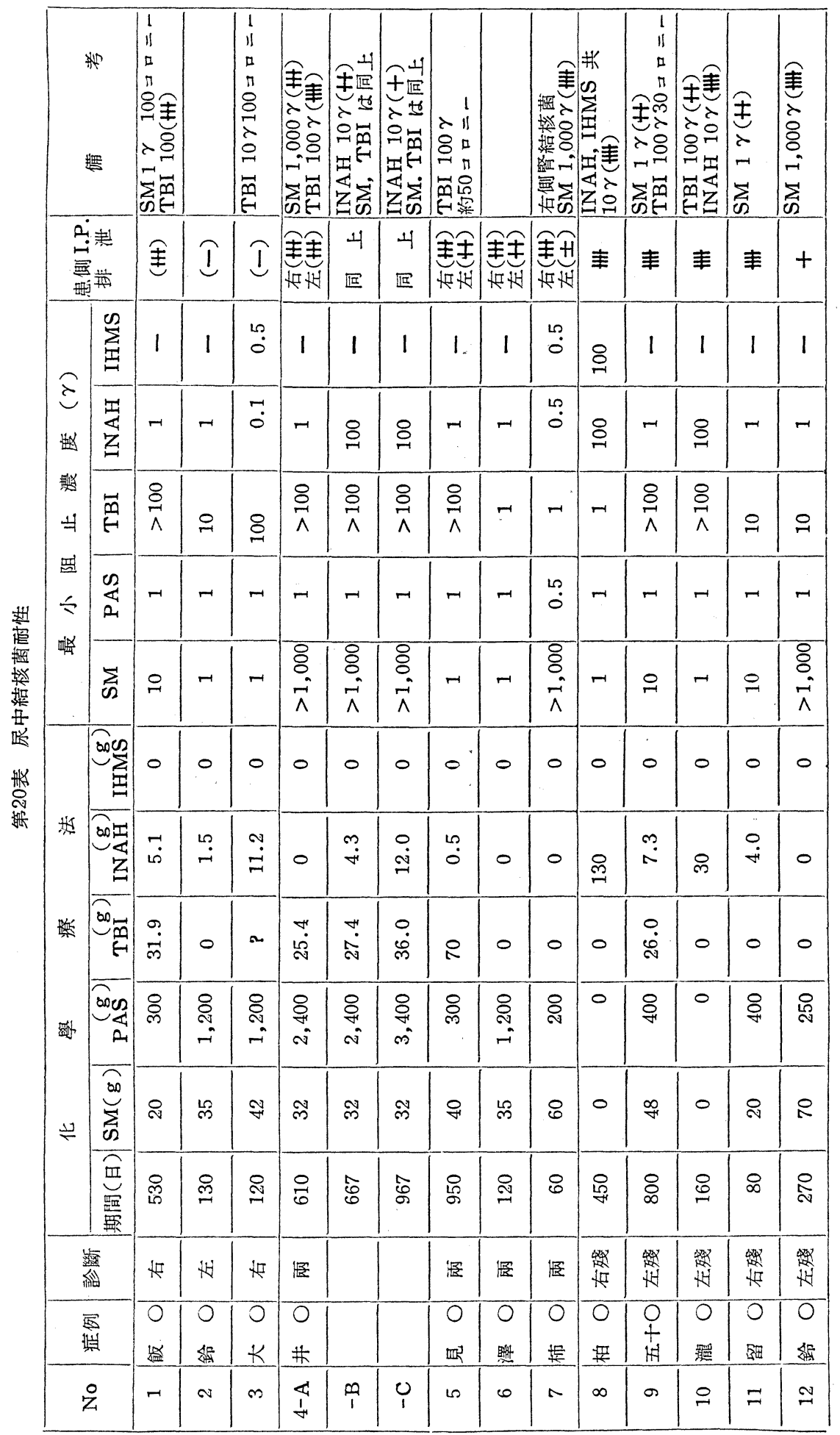


第 2 及び 3 例は患側の I.P. 排泄を認めない患者で, 前者は併用治療で而性菌はない。後者はT B I が10 迄 發育しているが，T B I治療の既往歴が判然としていな い. しかしSM, PAS, INAHについては併用治療 例であるためか, いづれにも感受性である.

兩側腎結核の第 $4 \sim 7$ 例中, 第 4 例は兩側共 I.P.の 排泄良好な症例であり，はじめに S M $32 \mathrm{~g}$ を45日間に使 用し, 次いでPAS 1 日 $10 \mathrm{~g}$ 150日間使用後T B I 1 日 $0.03 \sim 0.1 \mathrm{~g}$ を約 1 年間使用した. いづれの藥劑も單獨 治療であり，培養した結核菌の耐性注第20表 4-Aであ る. SM1,000 耐性, T B I $100 \gamma$ 耐性となつていた。 更にINAHとT B Iを併用した所一眭尿中結核菌の陰 性化を見たが, 約50日後に尿所見の惡化が起り, INA $\mathrm{H}$ 使用57日後の尿中結核菌の培養は陽性となつた $(4-$ B). 乙のとき I NAH注10 rの不完全耐性であり， S M， T B Iの耐性には變化が認められなかつた。その後 T B I, 次いでPASの使用後の結核菌の而性測定の結 果は 4-Cである, PA S は總計3,400 g 使用したけれぞ も尚感受性菌であり，SM，T B Iの耐性には變化を認

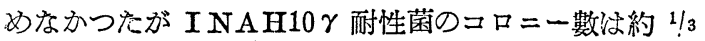
に減少した。

第 5 例は兩側共 I.P. の排泄良好な例で, T B I 單獨 約 2 年の長期投與により $100 \gamma$ 完全附性と成つていた.

S MとPA S は併用であるためか耐性を認めていない.

第 6 例も兩側の I.P. 排泄良好例であるが, SM $\mathrm{S} P$ A S の併用例であるためか耐性の出現を認めない.

第 7 例は他の病院にて SM PASの併用治療を行 つていたが，PASは胃腸障害が強く20日で投藥を中止 し，その後 S M 40 g 学單獨使用したものである. 初診㭙 に尿中結核菌は非常に多量認められた. I.P. によると右

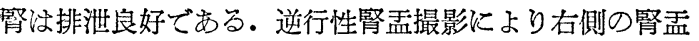
の狭窄々空洞形成安認め, 且つ右腎尿より結核菌培養陽 性であつた。この結核囷につき耐性を沮定した結果 S M $1,000 \gamma$ 耐性であること哭知つた。と心例はその後 SM とPASの併用治潦では効果を全く示さなかつた。

第 8 １2例㤝既に一側の腎剔除術学施行した残存腎結 核例であり，從つて抗結核劑孯腎より排泄されること は確實である.第8〜11例はいづれも LattimerのI〜 II群に屬する症例と考えられる．第８例はＩNAH單獨 治療18ケ月，第10例㤝 I NAH單獨 5 ケ月治療後の尿中 結核菌により耐性を测定したものて，共に I NAH10 r 耐性であつた。このうち前者は I HM S む $10 \gamma$ 耐性であ つた。兩例共にS MとPASの併用治療にして10ケ月及
び4ケ月治療で, 尿中結核菌注培養陰性, 尿所見は完全 に正常化している.

第 9 例怯初的にS M T T I I併用し, 次いでPAS と T B Iの併用治潦を施行したが，PASを中止してT B I 單獨治療を約 1 ケ年行つた。 その間尿中結核菌の 檢鏡及び培養は常に陰性であつた。次いで I NAHの單 獨治滰約30日を行つた所, 腎障害が起つたので，投藥定 中止した。休藥 4 ケ月目に尿中結核菌の琣養陽性己な り，その菌注 S M $1 \gamma / \mathrm{cc}$ 迄發育し, T B I $100 \gamma$ 不完 全耐性菌であるぶ，PAS 及びINAHに對しては感受 性菌であつた. 即ち長期單獨療法它行つたT B Iの及が 耐性となつたものである.との症例の残腎は Lattimer の分類では II 群に屬しているが，乙の程度の游變でさえ 上述の化學療法 2 年以上む不充分であることが分る. そ の後 S M と PA S 併用長期療法学施行中である.

第12例は約 5 年前に右腎剔除遇を受けた症例で, 初診 時のI.P.では腎杯に一致して圓形の造影劑排泄 3 箇を認 めた. S M と PA S の併用療法の豫定であつたが, PA S は嘔氣強く服用不可能であり, T B Iも胃腸障害強く服 用困難なためにSM 1 日 $1 \mathrm{~g}$ 單獨治療を行つた. S M 40 $\mathrm{g}$ 使用により尿所見注全く正常となり，尿中結核菌の检 鏡及び培養陰性であつた. しかし 2 ケ月の休藥により， 尿所見の惡化と結核菌が陽性化したので, 再び S M毎日 $1 \mathrm{~g}$ の治療学行つた。一時尿所見の改善と尿中結核菌の 陰性化を認めたが， $30 \mathrm{~g}$ 後 (即ち總計70g）に再び尿中 結核菌が多量に認められ, 培養も陽性となつた. この菌 は直接法も關接法でも S M $1,000 \gamma$ 耐性菌であり, 對照と 殆んぞ同數汇發育した。.その後のSM治療も全く効果な く結核性腹膜炎で死亡した. 尚とのS M $1,000 \gamma$ 而f性菌 は PA S, INAH及びT B I 店感受性菌であつた。

以上の結果より，抗結核劑の單獨使用は而性の出現し やすいとと, 特にSM, INAHでは耐性出現が迅速で あることを知つた。兩側腎結核, 残腎結核のように化學 療法の對象になる例は, 耐性の防止が大切であるから, 種々の抗結核劑の併用により, 副作用と耐性を防止しな がら長期の化學療法により最も効果的な治療を行うべき であろろ。

完全耐性の出現学見た症例は，その藥劑の效果安認め られないので，直ちに他の藥劑に變えるべきである.

口）剔除腎空洞内結核菌

剔除筲の空洞内より培養し得た結核菌16株について, 各種結核劑に對する耐性を測定した結果は第 21 表に示 す. 
第21表 空洞內結核菌の耐性

\begin{tabular}{|c|c|c|c|c|c|c|c|c|c|c|c|c|c|c|}
\hline \multirow{2}{*}{ 症 例 } & \multirow{2}{*}{ 患側 } & \multirow{2}{*}{$\left|\begin{array}{l}\text { 患側 } \\
\text { I.P. } \\
20 \text { 分 } \\
\text { 排泄 }\end{array}\right|$} & \multicolumn{2}{|r|}{ 化 } & 學 & \multicolumn{3}{|l|}{ 療 } & \multicolumn{5}{|c|}{ 最小阻止濃度 $(\gamma)$} & \multirow{2}{*}{ 備 } \\
\hline & & & \begin{tabular}{r|} 
日 \\
期間
\end{tabular} & $\mathrm{SM}^{\mathrm{g}}$ & PA $\stackrel{g}{\mathrm{~g}}$ & $\mathrm{TBI}^{\mathbf{g}}$ & $\mid \begin{array}{r}\mathbf{g} \\
\text { INA }\end{array}$ & IHM $\stackrel{\mathrm{g}}{\mathrm{S}}$ & SM & PAS & TBI & INAH & IHMS & \\
\hline 1. 萩O & 右 & -1 & 30 & 15 & 300 & - & -1 & - & 1 & 1 & 1 & 1 & - & \\
\hline 2. 寺 $\bigcirc$ & 右 & $H$ & 32 & 14 & 320 & - & 一 & - & 1 & 1 & 2 & 1 & - & \\
\hline 3. 今 $\bigcirc$ & 左 & - & 36 & 12 & 360 & - & 一 & 一 & $\begin{array}{l}\text { 1) } 1 \\
\text { 2) } 1\end{array}$ & $\begin{array}{l}1 \\
1\end{array}$ & $\begin{array}{l}1 \\
1\end{array}$ & 1 & - & 2 力所の空洞より分離 \\
\hline 4. 牧O & 右 & + & 70 & 21 & 700 & - & - & - & 1 & 1 & 10 & 1 & - & \\
\hline 5. 阿 $\bigcirc$ & 左 & $t$ & 53 & 27 & 170 & - & - & - & 10 & 1 & 10 & 1 & - & $\mathrm{SM} 1 \gamma(+)$ \\
\hline 6. 沬O & 左 & - & 105 & 32 & 1,000 & - & 0.96 & - & 1 & 1 & 10 & 1 & - & \\
\hline 7. 山О & 左 & - & 7 & - & 一 & - & 2.1 & - & 1 & 1 & 1 & 0.1 & 0.5 & \\
\hline 8. 龁 $\bigcirc$ & 右 & - & 30 & 8 & 240 & - & - & 1.6 & 1 & 0.5 & 2 & 0.5 & 0.5 & \\
\hline 9. 森O & 左 & - & 21 & - & - & - & 8.2 & - & 1 & 0.5 & 1 & 0.5 & 0.5 & \\
\hline 10. 栗O & 左 & $\mathrm{HH}$ & 30 & 10 & 280 & - & 0.9 & - & 1 & 1 & 1 & 0.1 & 0.1 & \\
\hline 11. 岡 $\mathrm{O}$ & 右 & + & 360 & 25 & 1,800 & - & 8.4 & - & 1 & 1 & 2 & 0.5 & 0.5 & \\
\hline 12. 富 $\mathrm{O}$ & 左 & $H$ & 54 & - & - & - & 16.2 & - & 1 & 1 & 1 & 10 & 10 & 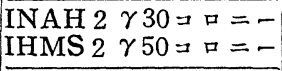 \\
\hline 13. 內О & 右 & $H$ & 40 & - & - & - & 12.0 & - & 1 & 1 & 2 & 2 & 2 & $\begin{array}{l}\text { INAH } 1 \gamma(+) \\
\text { IHMS } 1 \gamma(+)\end{array}$ \\
\hline 14. 大O & 右 & - & 120 & 42 & 1,200 & - & 11.2 & - & 1 & 1 & 2 & 0.1 & 0.5 & \\
\hline 15. 宮O & 左. & - & 120 & 35 & 1,200 & - & 1.8 & - & 1 & 1 & 1 & 0.1 & 0.1 & \\
\hline 16. 鈴 $\mathrm{O}$ & 右 & - & 14 & 7 & 50 & - & 4.2 & - & 1 & 1 & 1 & 0.1 & 0.1 & . \\
\hline
\end{tabular}

16例中耐性出現を認めた例はＩNAＨ單獨使用の第12 及び13例であり，共に忠側の I.P. 排泄に比較的良好で あつた。问この 2 例では I NAH使用前の尿中結椟菌は I NAH 0.5r/ccで阻止されていたが, 空洞内上り分鹳 した結核菌は 1 及び 2 耐性となつたものである。他の 症例中 2 例の I NAH單獨使用例以いづれも使用期間の 短かいもので，垡つた12例はいづれも併用治療であつた ためか，耐性の出現を見ていない.

耐性の出現した症例柱，いづれも I.P. の排泄が比較 的良好で，腎機能方良く保持されていたここは注目すべ きであり，Lattimer, Emmett等の報告によると SM單 獨治療では40g位より而性菌が出現るこいうが，彼等の 症例は一般に本邦症例より初期の例が多いと考えられ， 軗機能の良い例が多い故に，耐性の出現を認めるものと 考えられる. 渚者の例では，とのような小病集の再發例 が少いので結論安得るにはいたらないが, 小病巣といえ ぞも化學療法の文で治癒せしめるには，併用療法の長期 投藥が必要であることは推察し得る。

(6) 小 括

腎結核患者より分離した菌及び各種抗結核劑にて治療 した後に分離した結核菌について種々檢查した結果, 次 のととを認めた。
（1）化學療法未施行の腎結核患者より分離した結核 菌の最小阻止濃度は, 肺結核患者より分離した結核菌の 阻止濃度と大體一致して抎り, その阻止力は, INAH $>\mathrm{IHMS}>\mathrm{PAS}>\mathrm{SM}>\mathrm{TB}$ Iの順である。

（2）化學療法施行により，尿中及び空洞内の結核菌 のうち，檢鏡陽性であつても，一般に行われている培養 方法では㓌性で㐫る例定認める。

（3）結核菌の培養期間は，長期化學療法施行では普 通より長期間の觀察究必要とする例もある。

（4）尿路結核菌の耐性については

イ） SM：SMは 3 例 $(32 \mathrm{~g}, 60 \mathrm{~g}$, $70 \mathrm{~g}$ 使用例) 飞 $1,000 \gamma$ 而性菌の出現学見た. いづれも SM單獨治療例 であり,後 2 者は共に完全耐性と考えられ, S M治療は効 果字認めなかつた. 前者は 2 力年間つPAS, T B I, I NAHの治療にもか〉わらず, 耐性に變化はなかつた.

口） T B I : T B Iは比較的耐性になり難いといわれ ているが, 長期の單獨治療例 5例に $100 \gamma$ 耐性菌を認必 た.

八）PAS：PASは單獨使用例が少いが，比較的耐 性になり難いものと考えられる. $3,600 \mathrm{~g}$ 單獨使用例, 1 日 $5 \mathrm{~g} 360$ 日使用例も酎性以認めなかつた。

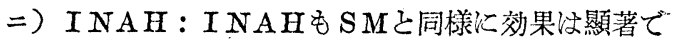


あるが，耐性の出現が早いので單獨使用注避けるべきで あろろ．尿中結核菌 3 例（57 日，160日，450日使用 例) に1 0 耐性菌学認めた他，空洞内結核菌 2 例洏性 菌を認めた. 尚 I NA H と I H S S に洨交叉耐性がある.

（5）剔除腎空洞内結核菌惊，36例中12例飞培盖不成 功であつた. 36例中铪鏡陽性33例であり，てのうち10例 は培養除性であつた。

（6）耐性の出現した場合には，その藥劑恲用して も他の抗結核劑の而栍阻止に役立たないようである.

\section{V. 考 按}

泌尿生殖器結核に種々の抗結核劑を施行した結果を中 心として現在の見解に考揬を下して見る。

\section{1）腎結核}

Lattimer の云う小病巢即ち O群に於いて, 抗結核 劑のみで治癒の可能性があること潩論がない所である が，か〉る症例を經驗することは非常に少い.乙の場合 に它再發する例があり，米國の報告に上れば再發例は耐 性を示すといわれて居り，著者の經驗でも腎機能が良好 な程, 尿所見の改善は著明であるが, 耐性が出現しやす いと思われるので， SM，INAH，IHMSの様に効 果が著明でも耐性の出現しやすい藥劑の單獨使用怡危險 であり，種々の併用潦法により効果を充分にあげるべき であらう. 又その使用期間も少い程再發の掞それがある 故, 長期使用がよい。

中病巢即与 I 及びII 群について現在の化學療法で以治 癒には不充分なることが多いので, 先づ化學療法により 經過を觀察して效果が不充分なる場合注，堲剔除乃至部

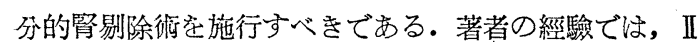
群即ち乳頭部に 1 個の結核性小空洞の疑いある例で, $\mathrm{S}$ $\mathrm{M}$ 單獨治療28g 亿して剔除した症例であるが，約 $20 \mathrm{~g}$ 使 用後より尿所見は全く正常で, 結核菌は陰性であり, そ の剔除㛑の組織學的影響は非常に効果を示したが, 空洞 内乾酪物質中に結核菌を認め且つ培養に成功している. この場合惊空洞寺剔除するか, 更に大量の化學療法によ り，乾酪物質中の結核菌を死隇せしめなりれば治澺は不 可能である. 從つて尿所見の改善, 結核菌尿の消失後も 當然長期の化學療法学施行しなければならない。

本邦に於ける督結核汸一般に發見が抢そい。從つて今 後注早期發見注意を向けるべきであろろ.

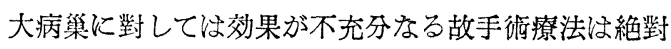
水必要である.との點に關して著者は S Mが空洞壁, 架
洞内に渗透不充分なるとと定既に報告したが, その組織 學的檢索でも使用量に比して效果が少く, 且つ細菌學的 にも結核菌陽性であり, 刃气の而性の出現む少い。結局 これ等の事實は大病巢に抗結核劑が到達しがたいととを 意味し, 治癒の困難を示すものである.

一側腎結核の手術の時期については, Albarran, Wildbolz以來の néphrectomie immédiate の方捨より, Fey の云了 Néphrectomie retardée 或惊 Thomas 等の delayed nephrectomy, Moonen の提唱する néphrectomie opportune に轉換して來たが, 理想的には サナトリウム療法と化學療法により充分加療して全身狀 態の改善学見てから néphrectomie opportune 施行 すべきである.との點について著者は他病院に於いて 不充分なる化學療法と剔除衡受け極めて初期の腎結 核であつたといわれた症例が, 他側の健康と思われた腎 に僅か 3 ケ月後に空洞を形成し來院し, その後の強力な 化學療法も病變を停止せしめるに到らなかつた症例を經 驗している. 即ちこれは 1 側珡結核が早期の場合には全 身症狀が進行性である許りでなく, 剔除により健腎と思 われる謷に負擔が非常に多くか〉るものと考允られ， Fey, Thomas, Moonenの主張の根據に成るとてろであ り，楠もかつる例い充分なる長期化學療法を必要とする とのべている様に注意ず゙き點であろう.

要するに腎剔除患者の㐨後が惡い理由として, 大部分 が結核性病變で死亡していることょり, 今後沙如何にし ててれ等の結核性病變を防止するかが化學療法汇課せら れた問題となるであろろ.

即与剔除後に必要な化學療法としては少くとも 8 カ月 以上の治療を要するものと考える.

兩側腎結核で 1 側が極めて輕度の場合は上記と同㥞な 方針で強力な化學療法により, 高度の 1 側の手術を施行 するか, 場合により爾側の部分的腎剔除琎定行うがよ W.

手術不可能なる兩側腎結核及び残腎結核には治虑不可 能であつても, その生命の延長て症狀の輕快を計るべき であるが, 著者の經驗では耐性が出現しやすいので, 特 に注意して使用し, 副作用を少くし有効に治療すべきで ある.併用療法としてS M注每日 $1 \mathrm{~g}$ 使用すると約 30 日 で副作用が現われる故, S M週 $2 \mathrm{~g}$ 已併用してPA S 10 $\mathrm{g}$ 以上, I NAH $0.3 \mathrm{~g}$ (或は I HMS $1 \mathrm{~g}$ ) 每日使用 するのが現在では最も有効な方法であると思われる。

I NAH, I HM S は腎結核飞著效を呈し, 且つ副作用 が少いので, 腎結核治療上に非常に希望が大きく战つた 


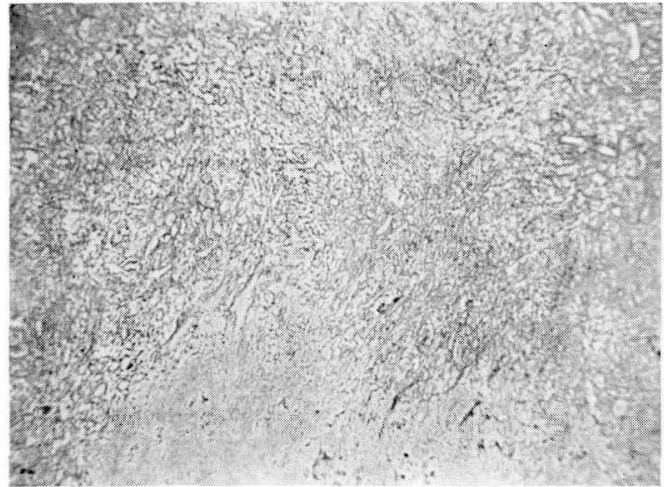

寫道 1 化學療法末施行例

腎空洞壁：乾酪物質が厚く附着，銀線維が空洞 內に移行卞. 鑛銀標本 $8 \times 10$

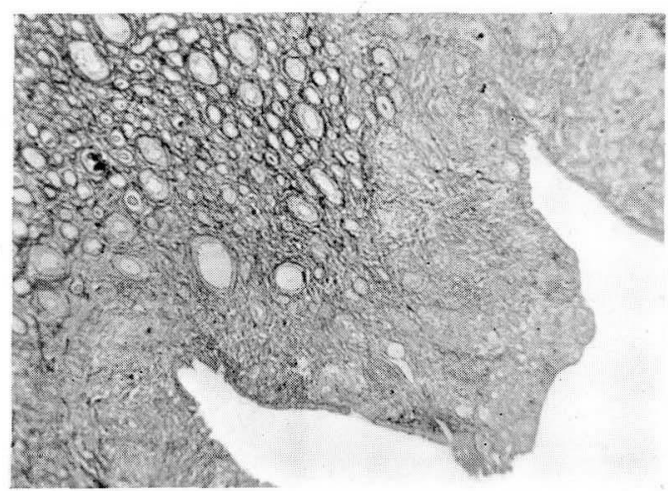

竄㯖 2 SM $33 \mathrm{~g}$

腎空洞壁：清淨化が進行し，上皮再生が起る. Azan 染色 $8 \times 10$

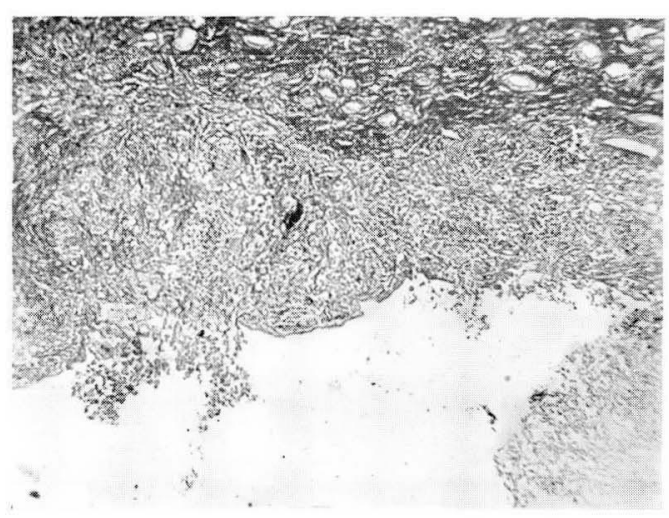

寫真 3 TBI $8.2 \mathrm{~g}$

腎空洞壁：一部清淨化が進み，上皮再生も起つ ている. Azan 染色 $8 \times 10$

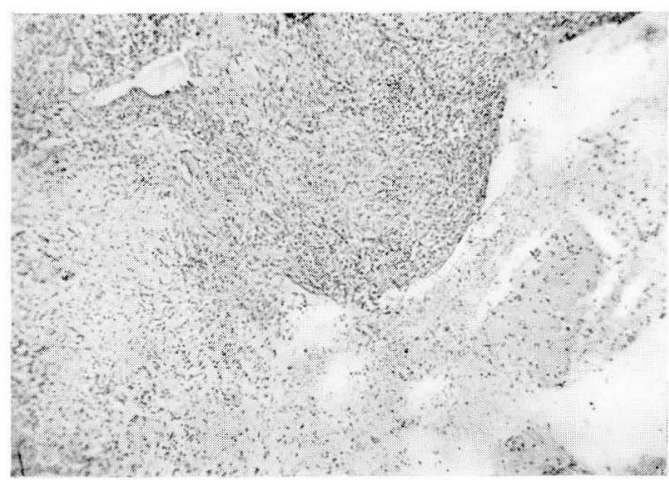

寫直 4 INAH $2.5 \mathrm{~g}$

腎空洞壁：一部に淸浮化が起つている，結核性 肉苸組織は萎縮し, 各細胞間は粗鬆と成る。 $\mathrm{H}$-E 染色 $8 \times 10$

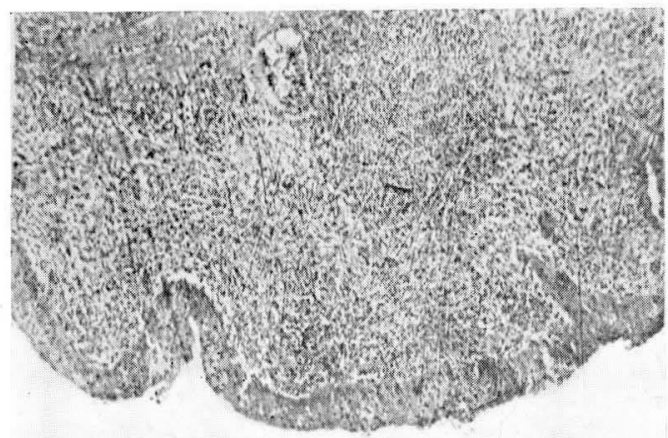

寫直5 INAH $14.3 \mathrm{~g}$

腎空洞壁：清淨化が起り上皮再生が著明である. H.E 染色 $8 \times 12$

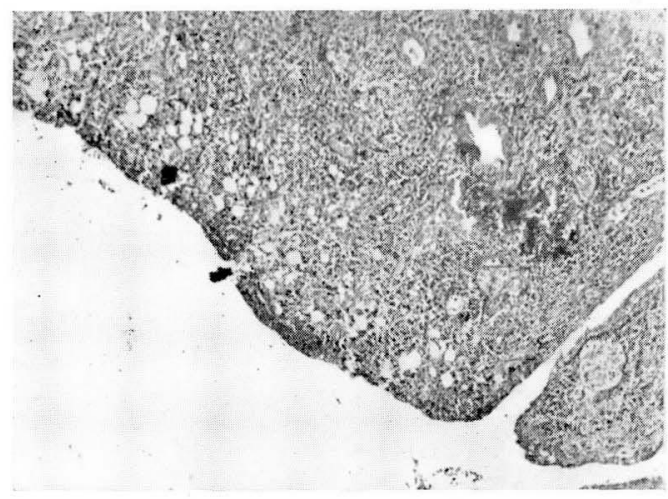

寫要 6 IHMS $132 \mathrm{~g}$

腎空洞壁：清淨化が起り，上皮再生が起つてい る。類上皮細胞層は空泡狀となる，H-E 染色 $8 \times 12$ 


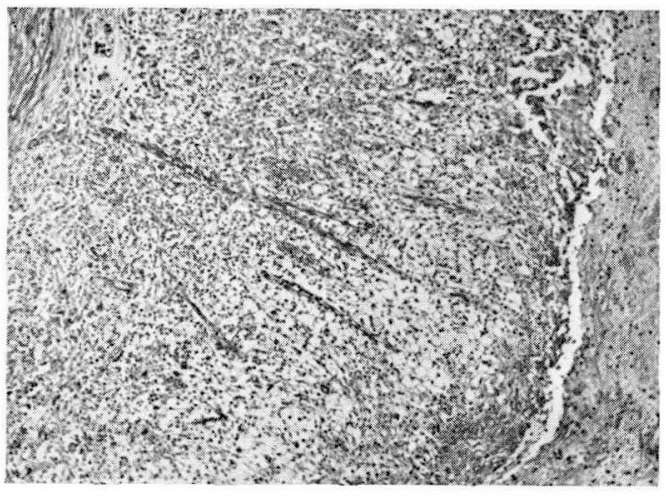

寫畺 7 IHMS $49 \mathrm{~g}$

空洞壁周邊の血管新生

Azan 染色 $8 \times 12$

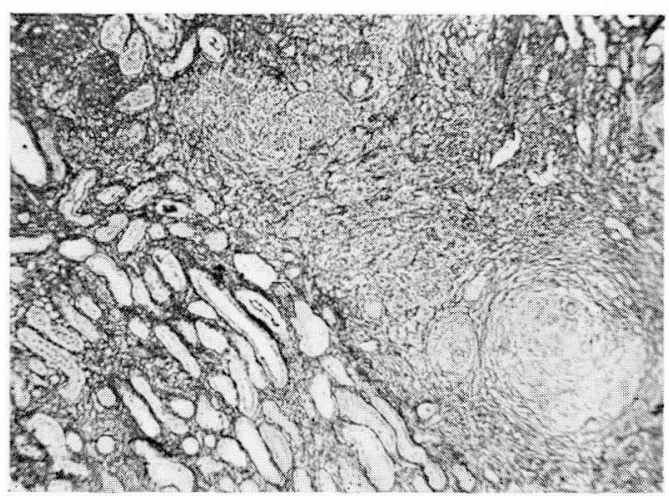

寫真 8 SM $94 \mathrm{~g}$, TBI $2.5 \mathrm{~g}$

結核結筆：類上:皮細胞は萎縮し粗鬆である。

鐄銀栖本 $8 \times 10$

わけである.

2, 膀腅結核

ずべての抗結核劑も效果学呈するる゙, 特にS M, I N $\mathrm{AH}$, I HMS 洨果が著明である。とれ等の治療に際 しては主として笲結核に主眼老置いて治療するがよい. 萎綰膀胱に成つた場合《種《の撗張手術を行う.

3. 副睪丸結核

化學燃法では極めて初期の症例のみに効果があるの で, 一度乾酸性變化が起つたならぼ效果は不充分なる 故, 化學療法施行中に剔出術老行引。

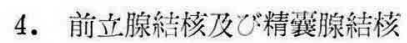

化學療法では効果が期待出來ない故, 症狀の強い場合 には手術療法安行うがよい。

\section{VI. 結 語}

（1）算結核 155例に化學療法を施行した結果次の知

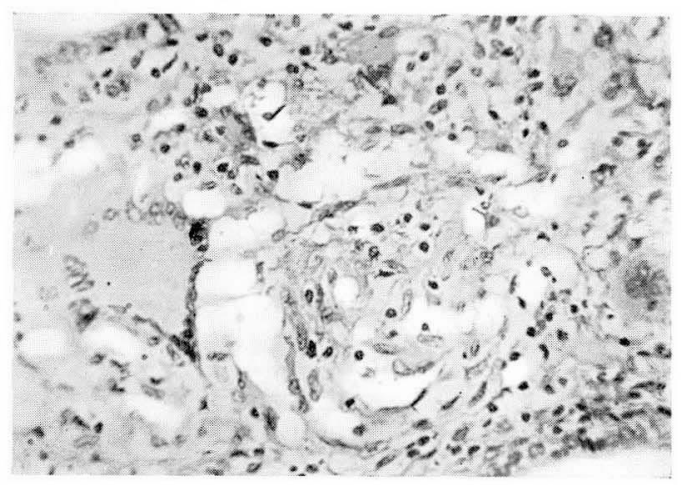

寫真 9 INAH $3.5 \mathrm{~g}$

比較的新しい結核結節：類上皮細胞の萎縮.

H.E. 染色 $40 \times 10$

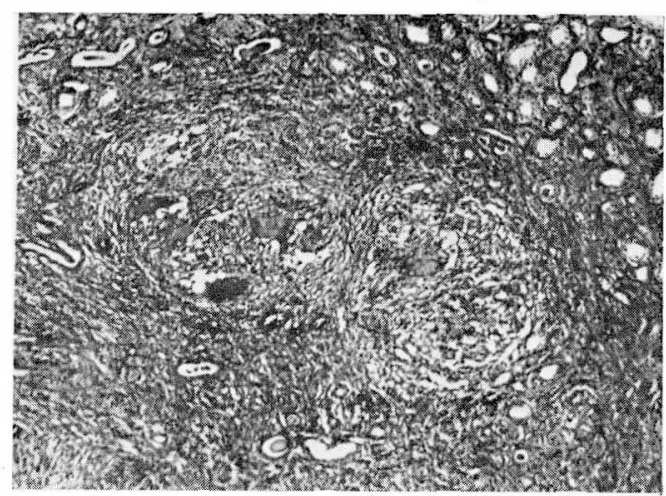

寫莚10 IHMS $49 \mathrm{~g}$

絬核結節：類上皮細胞の菱縮，巨細胞の變形

$\mathrm{H}$-E. 染色 $8 \times 12$

見老得庆。

イ) 各種の抗結核劑使用により尿所見の改善己尿中結 核菌の消失定热める. 尿所見の改善に對する效果的, S $\mathrm{M}=$ 併用 (1) $\geqq \mathrm{INAH}=\mathrm{I} \mathrm{HMS}>$ 併用 (2)>T B I ニ P54の順である.

口）尿所見の改善，尿中結核菌の陰性例も剔除後腎望 洞内に結核菌安認め, 培盖に成功する場合が多い。

八）腎組織に及无す影犁として，腎空洞内の乾酪物質 の減少, 空洞壁の清浄化と上皮再生, 類上皮細胞層の萎

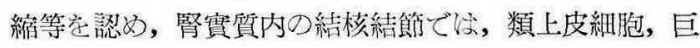

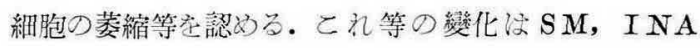
H， I HM S で顯著である. 又腎機能の度好な症例程迅 速で著明である.

））腎空洞内の清浄化々漻出炎の消退に伴つて尿所見 心改善すると考えられる。 
ホ）尿所胃が正常化して，腎組織の効果が著明な症例 も結核菌の培養に成功する例がある。

（2）膀胱結核 156例に化學橑法を施行して次のてと 定知つた。

1) $\mathrm{SM}, \mathrm{TB} I, \mathrm{INAH}$, I HMS, 併用 (1), 併用 (2)はいづれも効果を示し, 膀胱容量を増加し, 膀 胱粘膜の結核性變化を治瘾又は改善する。自覺症狀も輕 快消失する。

口) 膀胱結核の膀胱容量, 自覺症狀, 粘膜の病變に對 する効果は, S M =併用 (1)=I NAH=I HMS > 併 用 (2)> P A S > T B I = P54の順である.

（3）生殖器結核の化學療法により.

1）副莘丸結核には SM, T B I, I NAH, I HM $\mathrm{S}$ いづれも効果は不充分である.

口）前立腺結核及び精靁腺結核にも効果は不確實であ る.

（4） SM，PAS，INAHの吸收排泄を測定し た. SMは尿中に非常に高濃度に排泄されているととを 知つた.

(5) SM, PAS, TBI, INAH, IHMS 副作用を检索した. SM は每日 $1 \mathrm{~g}$ 使用で約 $30 \mathrm{~g}$ にして 副作用の出現する例が多い. T B Iでは種々の副作用を 認める場合が多い. I NAH, I HM S は比較的副作用 も少い。

（6）尿管狭窄，督孟狭窄については， SMで4 例, I NAHで 1 例, I HMSで 1 例を認めた.

（7）腎結核患者上り分離した結核菌について次の知 見学見た。

イ）化學療法未施行例の結核菌の最小阻止濃度を測定 した. その阻止力は, INAH $>$ I HMS $>$ PAS $>S$ $\mathrm{M}>\mathrm{T}$ B Iである。

口）化學療法施行例で, 尿中及び空洞内の結核菌のう 与鏡檢陽性，培養陰性例学認める。

八）長期化學療法施行例の空洞内結核菌は, 普通より 長期の培盖期間安要する例もある.

$\Rightarrow$ ）化學療法後の尿中結核菌の耐性測定により, SM 1,000 耐性菌, T B I 100 酎性菌, I NAH $10 \gamma$ 耐性 菌出現を認めた。いづれも單獨治療例である。

木） S M 1,000 r 完全耐性例 2 例は S M 治療により効 果を示さなかつた。

へ）剔除腎空洞内結核菌恃鏡检陽性例のうち約 $30 \%$ に 培養不成功であつた。

ト）耐性の出現した症例仙腎機能が良好に保持されて
いる場合が多く，又兩側及び残䯠結核に多かつた。片側 腎結核の場合には空洞内え抗結核劑が到達しないため耐 性の出現が少いのであろう.

本研究儿當り終始御想篤な御指導を御校閱を賜つた市 川敎授に哀心より感謝を捀げると共に, 種々御協力下さ れた呚室員諸兄に謝意を表する。

又本論交に關して病理學的の御指導を賜つた東京大學 病理學敎室岡前敎授及び佐々博士に深甚の感謝を表す る.

\section{主要文䣭}

1) Waksman, S.A. \& Lechevalier, H.A.: Science, 109, 305, 1949.

2) Domagk, G.: Am. Rev. Tuberc., 61, 8, 1950.

3 ) Graessle, O.T. \& Pietrowski, J.J.: J. Bact., 57, 459, 1949.

4) Rake, G. et al.: Am. Rev. Tuberc., 58, 479, 1948.

5) Walinsky, E., Reginster, A. \& SteenkenW. J. R.; Am. Rev. Tuberc., 58, 335, 1948.

6) 川上保雄, 他：結核, 25, 584, 1951.

7 ) 小酒井望：綜合醫學, 7, 1154, 1950.

8) 松田正三: 醫學研究, 23, 86, 1953.

9) Feldman, W.H.: Am. Rev. Tuberc., 52, 269, 1945.

10) Hinshan, H.C., Feldman, W.H. \& Pfuetze K.H.; J.A.M.A., 132, 668, 1946.

11) Alken, C.E. und Bücher, E.: Zschr. Urol., 45, 434, 1952.

12) Abernethy, A.C. \& Edelbrock, H.H.: J. Urol., 61, 410, 1949.

13）荒木龍爾,他：臨皮泌, 4, 453, 1950.

14) Bandler, C.G., Roen, P.R. \& Mulaire. V.J.: J. Urol., 59, 96, 1948.

15) Bravetta, G.: Zschr. Urol., 47, 293, 1954.

16) Cappellen, D.V.: J. Urol., 63, 333, 1950.

17) Cook, E.N. \& Greene, L.F. : J. Urol., 60, 187, 1948.

18) Cooper, H.G.: J. Urol., 72, 950, 1954.

19) Dean, L.A.: J. Urol., 73, 599, 1955.

20) Ericsson. N.O.: J.A.M.A., 144, 1031, 1950.

21) Faulkner, J.W., Carr, D.T. \& Emmett: Surg. Gyn. and Obs. Int. Abst., 28, 417, 1954.

22) Garvey, F.K.\& Tanning, T.R.: J. Urol., 60, $176,1948$.

23) Gow, J.G.: Brit. J. Urol. 25, 316, 1953.

24) Hermann, L.: J. Urol., 61, 122, 1949.

25) Halbeisen, K.: Zschr. Urol., 47, 280, 1954.

26) Huffines, T.R. \& Weber, W.D.: J. Urol., 62, $862,1949$.

27）市川篤二：日泌尿會誌, 42, 150, 1951. 
28）市川篤二, 大越正秋：化學とホルモン, 1, 137, 1948.

29）市川篤二, 大越正秋, 高安久雄：治療, 31，542, 1949.

30）稻田務他：臨床, 4, 478, 1951.

31）楠隆光：日結, 13, 394, 1934.

32）楠隆光, 他：日結, 12, 332, 1953.

33）楠隆光：最新醫學, 10, 1302, 1955.

34) Lattimer J.K.: Am. Rev. Tuberc., 67, 604, 1953.

35) Lattimer J.K., Amberson, J.B. \& Braham, S.: Am. Rev. Tuberc., 61, 518, 1950.

36) Lattimer J.K., Steans, W.H. et al.: J. Urol., 60, $974,1948$.

37) Lattimer J.K., Heryberg. A. et al.: J. Urol., 67, 750, 1952.

38) Lattimer J.K., et al.: J. Urol., 69, 745, 1953.

39) Lloyd, F.A.:Lattimer Discussion(36).

40) Ljunggren, E.: J. Urol., 67, 129, 1952.

41) Ljunggren, E.: Zschr. Urol., 47, 273, 1954.

42) Mathé, E.: J. Urol., 57, 451, 1947.

43) Nesbit, R.M. \& Bohne, A.W.: J. Urol., 60, $532,1948$.

44) Nesbit, R.M. \& Bohne, A.W.: J.A.M.A., 138. 937, 1948.

45) Nesbit, R.M. \& Thirlby, R.L.: J. Urol., 68, $394,1952$.

46) Nesbit, R.M. \& Mackinney, C.C.: J. Urol., 72, 296, 1954.

47) Meyer, J.: Zschr. Urol., 47, 311, 1954.

48) Nicolish, G.: Zschr. Urol., 47, 295, 1954.

49）中野柘, 他：醫學研究, 23, 1773, 1953.

50）大越正秋：腎結核, 醫學書院 (Tokyo) 1954.

51) Otto H.: Z. f. d. ges. Inn. Med., 7, 258, 1952.

52) Petković, S. \& Ilic, V.: Zschr. Urol., 47, 694, 1954.

53) Rinker, J.R.:J.A.M.A., 142, 87, 1950.

54) Ross J.C., Brit. J. Urol., 25, 277, 1953.

55) Ross J.C., Gow, G.J. et al.: Lancet, 1, 116, 1955.

56) Satterthwaite, R.W. \& White, T.T.: J. Urol., 60, 678, 1948.

57) Slotkin, J. C. \& Spencer, W.: J. Urol., 61, $658,1949$.

58) Taylor, J.A. :J. Urol., 59, 806, 1948.

59）土屋交雄：日結, 9, 64, 1950.

$60 ）$ 土屋文雄：日本醫事新報, No. 1513, 1591, 1953.

61）富川梁次：日泌尿會誌, 44, 209, 1953.

62）高安久雄：新藥と臨床, 2, 467, 1953.

63）高安久雄：綜合臨床, 3, 1145, 1954 .

64) 高安久雄, 堀內誠三: 診胘 と治療, $\mathbf{4 3}, 605,1954$.

65) Vries, V.: Zschr. Urol., 47, 293, 1954.
66) Wildbolz, E.: Zschr. Urol, 43, 333, 1950.

67) Fey. B.: J. d' Urol, 49, 383, 1941.

68) Beanfound.: cit. from Cappellen.

69) Medlar. E.M. et al.: J. Urol., 61, 1078, 1949.

$70 ＼mathrm{~ 市 川 篤 二, ~ 大 越 正 秋 . 他: ~ 日 泌 尿 會 誌, ~} 45,730,1954$.

71）宮川忠弘：臨皮泌, 8, 42, 1954.

72）土屋文雄：治療, 33, 131, 1951.

73 ) 矢口宏：臨皮泌, 8, 359, 1954.

74）大越正秋, 齋藤豐一：日本醫事新報, No. 1630 , 15,1955 .

75) Crofton, J. \& Mitchison, C.H.: Brit. Med. J., II, 1009, 1948.

76）佐及弘: 東京醫學雜誌, 61, 22, 1953.

77）岡治道他：日本醫事新報, No. 1503, 651, 1953.

78）岩崎龍郎：臨床, 4, 104, 1951.

79) 小見山主計：醫學㸴究, 23, 1758, 1953.

80）三谷久雄, 他：交通醫學, 5, 1, 1951.

81）赤崎而義：臨床, 3, 154, 1950.

82）森脇三郎：最新醫學, 6, 734, 1951.

83) Fey, B.: Press Med., 60, 7, 1952.

84) Dick, J.C.: J. Path., Bakt., 66, 365, 1953.

85) Dick, J.C.: Lancet, 2, 516, 1954.

86）鳥居敏雄, 他：J. Antibiotics, 3, 8, 1949.

87）宮村定雄, 他：臨床, 4, 678, 1951.

88）堀內誠三, 石山修二: 日泌尿會誌, 43, 441, 1952.

89）熊谷直：東北醫誌, $\mathbf{4 7}, 352,1953$.

90）坂本公考：醫學㸴究， 23, 72, 1953.

91）木村元, 他：ペニシリン, 3, 53, 1949 .

92）海老名敏明：短療, 4, 506, 1950.

93) Scherman-Warcyewski: Anales de Medicine, $51,1950$.

94) Feldman, W.H. et al.: Am. Rev. Tuberc., $\mathbf{5 7}, \mathbf{1 6 2}, 1948$.

95) Levin, C. el al.: Am. Rev. Tuberc., 58, 531, 1948.

96) Seidal \& Bittner: cit. from Okoshi.

97) Lehman, J.: Lancet., 1, 15, 1946.

98) Carstensen, B.O.: Am. Rev. Tuberc., 61, $621,1950$.

99）小山征助, 他：日泌尿會誌, 41, 83, 1950.

100）根岸博, 他：治療, 32, 1044, 1950 .

101) Razaz, L.: Schweiz Med. Wschr., 78, 332, 1948.

102) Dempsy, J.G. \& Logg, M.H.: Lancet, 2, 871, 1747.

103) Graessle, O.E. \& Pietrowski, J.J.: J. Bact., 57, 459, 1949.

104) Karlson, A.G. et al.: Proc. Staff. Meet. Mayo Clin., 24, 544, 1949.

105) Marschall, E.K.: Proc. Soc. Exper. Biol. \& M., 68, 471, 1948.

106) Way E. et al.: J. Pharm. \& Exp. Ther., 93, 
$368,1948$.

107) Alin, K. and Difs, H.: Nord. Med. 33, 151, 1947.

108）北本治, 他：臨床, 3, 223, 1950.

109) Horne, N.W. et al.: Lancet, 2, 17, 1949.

110) Boger, W.P. \& Pitto, F.W.: Am. Rev. Tuberc., 62, 610, 1950.

111) Domagk G.: Am. Rev. Tuberc., 61, 21, 1949,

112) Benisch, R. et al: Am. Rev. Tuberc., 61, 1, 1950.

113) Domagk, G.: cit. from " Zur. Chemotherapie der Tuberkulose mit Conteben" 1951, Bayer.

114）堂野前維摩鄉他：日本臨床, 8, 700, 1950.

115) Boshamer, K.: cit. from "Zur. Chemotherapie der Tuberkulose mit Conteben" 1951. Bayer.

116）川村太郎, 他：治療菜報, 475, 3, 1951 .

117）外松茂太郎,他：皮䖉科紀要, 47, 271, 1951.

118）佐々弘：日病學會誌, 43, 51, 1952.

119）田村峯雄,他：皮膚科紀要，48，425，1952。

120) Wollenberg, O.: Deut. Med. Wschr. 75, 899, 1950.

121) Heilmyer, L.: Deut. Med. Wschr., 75, 473, 1950.

122）坂口康藏,他：最新醫學, $\mathbf{9}, 1095,1954$.

123）小川政敏, 他：最新醫學, 9, 119, 1954.

124) Hoggarth, E. et al.: Brit. J. Pharm. Chem., 4, 288, 1949 .

125) Donovick, R. et al.: J. Bact., 59, 667, 1950.

126) Hamre, D, et al.: J. Bact, 59, 675, 1950.
127）北本治：プッント, 1951,

128）島本多喜雄：日雄醫事新報, No. 1406, 3, 1951.

129) Bernstein, J. et al.: Am. Rev. Tuberc., 65, $357,1952$.

130) Benson, W.M. et al.: ibid., 65, 376, 1952.

131) Robitzek, E.H. et al.: ibid., 65, 402, 1952.

132) Domagk, G.: Dsch. Med. Wschr., 77, 573, 1952.

133) Middlebrock, G.: Am. Rev. Tuberc., 65, 765, 1952.

134) Pansy, F. et al.: ibid., 65, 761, 1952.

135) Stenken, W. et a1.: ibid., 65, 365, 1952.

136）岩崎太郎, 他：新藥と臨床, 2, No. 8, 47, 1953.

137）市川篤二, 高安久雄, 他：最新醫學, 8, 633, 1953 .

138) Lattimer, J.K.: J.A.M.A., 150, 981, 1952.

139）市川篤二，岡治道,他：治療, 35, 77, 1953.

140) Dick J.C.: Lancet, 1, 808, 1953.

141）北本治：最新醫學, 6, 438, 1954.

142）市川篤二, 他：新藥と臨休, 3, 550, 1954.

143）小川辰次：最新醫學, 6, 581, 1951.

144）日本醫事新報, No. $1490,45,1952$.

145) Hobby, G.L. et al.: Am. Rev. Tuberc., 70, 191, 1954.

146）小川辰次, 他：日本醫事新報, No. $1627,20,1955$.

147）龜山禧, 他：Chemotherapy, 3. 92, 1955.

148) Sivertson, S.E. et al.: Proc. Staff. Meet. Mayo Clin., 28, 554, 1953.

149) Rake G. \& Donovick, R.: Proc. Soc. exp. Biol. Med., 62, 31, 1946.

150）高橋照三：最新醫學, 10, 648, 1955. 